\title{
NEURITE OUTGROWTH AND PROTEIN SYNTHESIS BY PC12 CELLS AS A FUNCTION OF SUBSTRATUM AND NERVE GROWTH FACTOR ${ }^{1}$
}

\author{
DENNIS K. FUJII, SHARON L. MASSOGLIA, NAPHTALI SAVION, AND DENIS GOSPODAROWICZ ${ }^{2}$ \\ Cancer Research Institute and the Departments of Medicine and Ophthalmology, University of California Medical Center, \\ San Francisco, California 94143
}

Received November 16, 1981; Revised March 11, 1982; Accepted March 26, 1982

\begin{abstract}
Numerous studies have implied that enhanced cell-substratum adhesion plays a role in neurite outgrowth by neuronal cells. Using an extracellular matrix (ECM) produced by cultured corneal endothelial cells, we have investigated attachment and de novo neurite outgrowth by the pheochromocytoma cell line, PC12. PC12 cells were found to attach more rapidly and efficiently to the ECM than to plastic or collagen-coated surfaces. An extensive but temporary (5- to 10-day) neurite outgrowth occurred in the absence of nerve growth factor (NGF) when cells were on the ECM. However, long term neurite survival and further elongation required NGF. Our findings are consistent with the hypothesis that protein(s) in the ECM has an important role in neurite outgrowth. Thus, NGF may not so much initiate neurite outgrowth as it stabilizes neurites.

ECM and NGF also were found to modulate cellular protein synthesis by PC12 cells. On ECM, a decreased synthesis of many high molecular weight proteins $\left(M_{\mathrm{r}}>85,000\right)$ was observed in comparison to that of cells on collagen-coated dishes. The presence of neurites (in the presence or absence of NGF) was associated with the induction of the synthesis of a cellular protein $\left(M_{\mathrm{r}}=\right.$ 55,000 to 56,000 and $\mathrm{pI}$ of 5.6). NGF was found to increase markedly the synthesis of two secreted proteins, while it drastically reduced the synthesis of all others regardless of the substratum upon which the cells were maintained.
\end{abstract}

Among the various factors which can influence axonal growth in vivo are chemotactic and/or trophic factors, such as $\mathrm{NGF}^{3}$ (Varon and Bunge, 1978; Greene and Shooter, 1980; Vinores and Guroff, 1980), contact guidance (i.e., fasciculation) (Johnston and Wessells, 1980; Buskirk et al., 1980), and the physicochemical interaction of actively growing nerve fibers with the various sub-

\footnotetext{
${ }^{1}$ This work was supported by United States Public Health Service Research Grant EY-02186. We wish to thank I. S. Wood and M. T. Maglio for the transmission and scanning electron microscopy (facilities supported by Core Grant EY-02162). We would also like to thank Dr. B. Howard (UCLA) for initially describing the PC12 cells to us. The invaluable assistance of $\mathrm{H}$. Scodel in the preparation of the manuscript is gratefully acknowledged.

${ }^{2}$ To whom correspondence should be addressed at Cancer Research Institute, M 1282, University of California, Medical Center, San Francisco, CA 94143.

${ }^{3}$ The abbreviations used are: Ara $\mathrm{C}$, cytosine arabinoside; $\mathrm{BCE}$, bovine corneal endothelial; dbcAMP, dibutyryladenosine $3^{\prime}: 5^{\prime}$-cyclic monophosphate; DMEM, Dulbecco's modified Eagle's medium; DPBS, Dulbecco's phosphate-buffered saline; DTT, dithiothreitol; ECM, extracellular matrix; EDTA, ethylenediaminetetra-acetate; FGF, fibroblast growth factor; $\mathrm{GuHCl}$, guanidine- $\mathrm{HCl}$; $\mathrm{HNO}_{2}$, nitrous acid, $\mathrm{NGF}$, nerve growth factor; $\mathrm{NH}_{4} \mathrm{OH}$, ammonium hydroxide; $\mathrm{PBS}$, phosphatebuffered saline; SDS, sodium dodecyl sulfate; TCA; trichloroacetic acid.
}

strata that they encounter during the elongation process (Johnston and Wessells, 1980; Solomon, 1981).

The role of cell-substratum adhesion in the initiation, elongation, and branching of axons from either embryonic or neonatal sympathetic, parasympathetic, or sensory neurons or from neuronal tumor cell lines has been the object of numerous in vitro studies (Luduena, 1973; Helfand et al., 1976; Letourneau, 1975a, b, 1979; Schubert and Whitlock, 1977; Schubert et al., 1978; Collins, 1978a, b, 1980; Collins and Garrett, 1980; Hawrot, 1980; Adler and Varon, 1981). These studies have led to the conclusion that there is a strong correlation between substratum adhesion and enhanced neuronal morphogenesis. This suggests that the adhesive interaction between the nerve cells and their microenvironment could be a crucial part of the initiation and elongation of neurons. Regulation of neuronal morphogenesis therefore may be expressed in part through the physicochemical properties of the interacting cell surface and its extracellular environment. However, in most cases, the substrata considered have been artificial in nature, consisting of plastic, chemically modified surfaces (palladium-, polyornithine-, or polylysine-coated surface), or collagen gels, as well as killed non-neuronal cells and uncharacterized 
substratum-associated material produced by non-neuronal cells.

Cultured bovine corneal endothelial cells retain their ability to produce an extensive ECM (Gospodarowicz and Greenburg, 1981). This ECM, as characterized in previous studies, is composed of collagen types I:III:IV and V present at a ratio of 3:16:1 (Tseng et al., 1981). Associated with the collagens are proteoglycans and glycosaminoglycans that consist of heparan and chondroitin sulfates (Gospodarowicz and Greenburg, 1981; Nevo et al., 1982). Fibronectin and laminin (a marker for basal lamina; Timpl et al., 1979) also are present (Gospodarowicz et al., 1978, 1981). This ECM therefore has the biochemical composition of a basal lamina composed of a lamina lucida and a lamina densa (Foidart et al., 1980; Gospodarowicz et al., 1981).

The ability of cultured BCE cells to produce a matrix similar to those found in vivo gives us an opportunity to study the properties of a natural substratum with regard to nerve cell adhesion and the subsequent neurite initiation and outgrowth. It also allows us to study how the response of nerve cells to trophic and chemotactic agents, such as NGF, may differ from the response previously observed when cells were maintained on various artificial substrata.

The rat pheochromocytoma cell line $\mathrm{PC12}$, which shares many properties with cultured sympathetic ganglion cells (Greene and Shooter, 1980), was selected to study the role of cell-substratum interaction in regulating nerve cell attachment, neurite outgrowth, and protein synthesis. The advantage of using PC12 cells instead of normal sympathetic neuronal cells is that, although these cells do not require NGF in order to survive, they have been shown to respond to it by initiating de novo neurite outgrowth on certain substrata (Greene and Tischler, 1976).

\section{Materials and Methods}

Materials. DMEM (H-16), DPBS, glutamine, methionine-free RPMI 1640, PBS, penicillin, RPMI 1640, and streptomycin were obtained from Grand Island Biological Co. (Grand Island, NY). Horse serum (heat inactivated) was obtained from KC Biologicals, Inc. (Lenexa, KS). Calf serum and fetal bovine serum were from Irvine Serum Co. (Irvine, CA). Tissue culture plastic dishes (Falcon) were from Becton-Dickinson Labware, (Oxnard, CA), Garamycin was from Schering-Plough Corp. (Kenilworth, NJ), and Fungizone was from E. R. Squibb \& Sons, Inc. (Princeton, NJ).

Mouse $7 \mathrm{~S}$ and $\beta$-NGF were generously provided by Drs. L. F. Reichardt, K. Greif, and D. Shelton (University of California, San Francisco). Antiserum to mouse $\beta$ NGF was a gift from Drs. C. E. Chandler, T. Darling, and E. M. Shooter (Stanford University). Actinomycin D was from Calbiochem (La Jolla, CA). $\mathrm{NH}_{4} \mathrm{OH}$, cobalt chloride, glacial acetic acid, sodium nitrite, and other chemicals were reagent grade from Mallinckrodt (Paris, KY). Ara C, $\alpha$-chymotrypsin type IV (recrystallized three times), cycloheximide, dextran $\left(M_{\mathrm{r}}=40,000\right)$, dbcAMP, DTT, gelatin, glyoxylic acid, $\mathrm{GuHCl}, \mathrm{L}$-methionine, $p$ nitrophenyl- $\beta$-D-xylopyranoside (xyloside), poly-D-lysine $\operatorname{HBr}\left(M_{\mathrm{r}}=360,000\right)$, and trypsin form III (recrystallized twice) were from Sigma (St. Louis, MO). Chondroitinase ABC was obtained from Miles Laboratories (Elkhart, IN). Collagenase was from Worthington Biochemical Corp. (Freehold, NJ). Human plasma fibronectin was from Collaborative Research (Waltham, MA) and bovine skin collagen (Vitrogen 100, 95\% type I and 5\% type III) was obtained from Collagen Corp. (Palo Alto, CA). Gelvatol 20-30 (polyvinyl alcohol) was obtained from Monsanto (St. Louis, MO). SDS and sucrose were from BioRad (Richmond, CA) and ultrapure urea was obtained from Schwartz/Mann (Orangeburg, NY). Ampholine ( $\mathrm{pH}$ 3.5 to 10 ) was purchased from LKB Instruments (Rockville, MD), and Nonidet $\mathrm{P}-40$ was purchased from Particle Data, Inc. (Elmhurst, IL). $\left[{ }^{35} \mathrm{~S}\right]$ Methionine (800 to $1300 \mathrm{Ci} / \mathrm{mmol}$ ) was from Amersham Corp. (Arlington Heights, IL).

Cell culture conditions. The clonal rat pheochromocytoma line, PC12, was the generous gift of Dr. Lloyd A. Greene (New York University Medical Center). Cultures were maintained as described by Greene and Tischler (1976) with the addition of Garamycin. Cells were grown in RPMI 1640 supplemented with $10 \%$ heat-inactivated horse serum, $5 \%$ fetal bovine serum, $2 \mathrm{~mm}$ glutamine, 50 $\mu \mathrm{g} / \mathrm{ml}$ of Garamycin, 100 units $/ \mathrm{ml}$ of penicillin, and 100 $\mu \mathrm{g} / \mathrm{ml}$ of streptomycin (growth medium). Cultures were maintained at $37^{\circ} \mathrm{C}$ in a humidified $5 \% \mathrm{CO}_{2}$ incubator. Stock cultures $(30 \mathrm{ml})$ had one-half of the medium volume changed three times weekly. Stock cultures with a cell density of 2.5 to $3 \times 10^{5}$ cells $/ \mathrm{ml}$ were used to initiate all experiments. Experimental cultures had one-half of the volume changed every other day with NGF added if previously present.

The University of California, San Francisco Cell Culture Facility screened stock cultures for Mycoplasma by DNA staining (Chen, 1977), culturing (McGarrity et al., 1979), and fluorescent antibody staining (Barile et al., 1973). The results were negative. The screening for other microbial contaminations was also negative.

Cultures of BCE cells were established from steer eyes as already described (Gospodarowicz et al., 1977; Gospodarowicz and Greenburg, 1979). Stock cultures were maintained in the presence of DMEM supplemented with $10 \%$ fetal bovine serum and $5 \%$ calf serum, $2 \mathrm{~mm}$ glutamine, $2.5 \mu \mathrm{g} / \mathrm{ml}$ of Fungizone, and $50 \mu \mathrm{g} / \mathrm{ml}$ of Garamycin in a humidified $10 \% \mathrm{CO}_{2}$ incubator. BCE cultures used to coat plastic dishes with an ECM were grown as described above but with $10 \%$ calf serum and $5 \%$ dextran. Bovine vascular endothelial cell cultures were established from adult bovine aortic arch (Gospodarowicz et al., 1976). Cell stocks were maintained routinely in DMEM supplemented with $10 \%$ calf serum, 2 $\mathrm{mm}$ glutamine, $2.5 \mu \mathrm{g} / \mathrm{ml}$ of Fungizone, and $50 \mu \mathrm{g} / \mathrm{ml}$ of Garamycin. To both cell types, FGF $(100 \mathrm{ng} / \mathrm{ml})$ was added every other day until the cells reached confluence (Gospodarowicz et al., 1978). Xyloside-treated ECM was prepared as above but with the addition of xyloside (125 $\mu \mathrm{M})$ at the time of seeding (Nevo et al., 1982).

Coating of plastic tissue culture dishes with either collagen or ECM. Tissue culture dishes $(35 \mathrm{~mm})$ were coated with bovine skin collagen $(10 \mu \mathrm{g} / 250 \mu \mathrm{l}$ in distilled water). The collagen solution was spread as a film over the dish and allowed to dry at room temperature in a sterile laminar flow hood. This amount of attached col- 
lagen was found to yield optimal cell attachment in $24 \mathrm{hr}$ (D. K. Fujii, S. L. Massoglia, N. Savion, and D. Gospodarowicz, unpublished results). Dishes were coated with gelatin by incubating $1 \mathrm{ml}$ of a $0.2 \%$ solution per $35-\mathrm{mm}$ dish at $4^{\circ} \mathrm{C}$ overnight, followed by washing with DPBS.

Plastic dishes $(35 \mathrm{~mm})$ or glass coverslips coated with an ECM produced by BCE cells were prepared using an alkali treatment. Confluent $\mathrm{BCE}$ cultures were exposed to $0.02 \mathrm{M} \mathrm{NH}_{4} \mathrm{OH}$ in distilled water for $5 \mathrm{~min}$, followed by washing and storage with antibiotics in DPBS at $4^{\circ} \mathrm{C}$. The presence of cytoskeletal elements (actin and vimentin) or nuclei could not be detected on the denuded ECMs when the plates were examined by phase contrast microscopy, scanning electron microscopy, or indirect immunofluorescence using either specific antibodies directed against actin or vimentin or the bisbenzimidazole derivative Hoechst 33258 for nuclear staining (Gospodarowicz et al., 1981).

PC12 cell adhesion and neurite extension assays. Cells were exposed to $0.25 \%$ trypsin solution in PBS for $15 \mathrm{~min}$ at $37^{\circ} \mathrm{C}$. This treatment dissociated cell aggregates into $85 \%$ single cells at a minimum, with the remainder consisting of clumps composed of less than 5 cells. Aliquots of the cell suspension were counted in a Coulter counter, and 1 to $4 \times 10^{5}$ cells in $2 \mathrm{ml}$ of growth medium then were seeded on tissue culture dishes or dishes coated with either collagen or ECM for cell attachment assays. The dishes then were incubated at $37^{\circ} \mathrm{C}$ for various times (from $10 \mathrm{~min}$ to $24 \mathrm{hr}$ ) in a $5 \%$ $\mathrm{CO}_{2}$ incubator. At various time intervals, duplicate plates were washed in order to remove unattached or poorly attached cells. The plates then were trypsinized (STV solution; trypsin $(0.05 \%)$, EDTA $(0.02 \%)$ in a PBS solution; Difco Laboratories, Detroit, MI) to release attached cells and then counted in a Coulter counter. A similar procedure was used to determine the number of cells per plate in other experiments.

For neurite extension assays, cells were dissociated as described above and then plated at 4 to $5 \times 10^{4}$ cells $/ 35$ $\mathrm{mm}$ dish in $2 \mathrm{ml}$ of growth medium. Cultures then were maintained for various times in a $5 \% \mathrm{CO}_{2}$ incubator at $37^{\circ} \mathrm{C}$. Phase contrast photographs of the cultures were taken al various time intervals and enlarged for scoring. Usually 100 to 500 cells were scored per time point and experimental condition. Cells were scored as having neurites if the projection was $20 \mu \mathrm{m}$ or more in length or if a branch point was observed. All experiments were performed at least two times with similar results.

Chemical and enzymatic treatment of ECM. In order to elucidate the nature of the molecular components in the ECM responsible for neurite outgrowth, ECM-coated dishes were subjected to a number of chemical and enzymatic treatments as described below (Gospodarowicz and Greenburg, 1981).

ECM-coated dishes were exposed at $37^{\circ} \mathrm{C}$ for $30 \mathrm{~min}$ to $1 \mathrm{ml}$ of DTT $(100 \mathrm{~mm})$ or $\mathrm{NH}_{4} \mathrm{OH}(14 \mathrm{M})$. All dilutions were made in distilled water. Dissociation or degradation of glycosaminoglycans was accomplished by treating the ECM with 1 M GuHCl (Sajdera and Hascall, 1969; Hascall and Sajdera, 1969; Rollins and Culp, 1979) or 2.5\% nitrous acid (Cifonelli, 1968; Castellani et al., 1970; Lindahl and Roden, 1972) for $30 \mathrm{~min}$ at $37^{\circ} \mathrm{C}$.

The effects of proteases, collagenase, and glycosidase were examined. Trypsin, $\alpha$-chymotrypsin, and collagenase were dissolved in PBS ( $\mathrm{pH} 7.4)$ at a final concentration of $0.1 \%$. Chondroitinase ABC was dissolved in enriched Tris buffer at pH 8.0 (Saito et al., 1968) and used at $1 \mathrm{unit} / \mathrm{ml}$. One milliliter was added per dish and incubated for $30 \mathrm{~min}$ at $37^{\circ} \mathrm{C}$.

Chemically or enzymatically treated ECM then was washed extensively with DPBS.

Coating dishes with conditioned medium from bovine vascular and corneal endothelium. Bovine vascular and corneal endothelial cell-conditioned medium was prepared by exposing confluent dishes $(10 \mathrm{~cm})$ to $10 \mathrm{ml}$ of DMEM supplemented with $2 \mathrm{~mm}$ glutamine, $50 \mu \mathrm{g} / \mathrm{ml}$ of Garamycin, 100 units $/ \mathrm{ml}$ of penicillin, $100 \mu \mathrm{g} / \mathrm{ml}$ of streptomycin, and $2.5 \mu \mathrm{g} / \mathrm{ml}$ of Fungizone for 5 days at $37^{\circ} \mathrm{C}$. The conditioned medium was filtered through a $0.45-\mu \mathrm{m}$ Millipore filter.

To enhance the attachment of components in conditioned medium to culture dishes, the dishes were incubated with $1 \mathrm{mg} / \mathrm{ml}$ of poly-D-lysine in $0.1 \mathrm{M}$ sodium borate $(\mathrm{pH} 8.4)$ at $4{ }^{\circ} \mathrm{C}$ overnight. After washing with distilled water, $2 \mathrm{ml}$ of conditioned medium was added and the dishes were kept at $4^{\circ} \mathrm{C}$ overnight. The plates were washed with DPBS.

Human plasma fibronectin $(1 \mathrm{mg} / \mathrm{ml}$ ) was coated on dishes precoated or not with poly-D-lysine or collagen as described by Orly and Sato (1979). Bovine plasma fibronectin was isolated by the procedure of Ruoslahti et al. (1978) and coated on dishes at $\mathrm{pH} 6.0,6.5$, and 7.2 as described by Akers et al. (1982).

Transmission and scanning electron microscopy. For transmission electron microscopy studies, the culture medium was removed from the dishes and replaced with a $1.5 \%$ paraformaldehyde/glutaraldehyde fixative with $0.068 \mathrm{M}$ sodium cacodylate buffer ( $\mathrm{pH} 7.4$ ) and $0.2 \%$ calcium chloride. The cells then were postfixed in $1 \%$ osmium tetroxide in Veronal acetate buffer with the addition of $1 \%$ postassium ferricyanide for $2 \mathrm{hr}$. Following the postfixation, the cells were stained en bloc in $0.5 \%$ uranyl acetate, dehydrated, and embedded in Araldite 502. Ultrathin sections were cut on a Sorvall MT-2B microtome, stained with uranyl acetate followed by lead citrate, and then examined with a JEOL $100 \mathrm{C}$ electron microscope. Samples for scanning electron microscopy were fixed as above, subjected to $\mathrm{CO}_{2}$ critical point drying, and coated with $\mathrm{Au} / \mathrm{Pd}$. The samples were examined in a JEOL $35 \mathrm{U}$ scanning electron microscope.

Catecholamine fluorescence. Catecholamine fluorescence of PC12 cells was induced by the glyoxylic acid conjugation described by de la Torre (1980). Trypsinized cells were seeded onto ECM-coated glass coverslips and placed in 35-mm dishes with $2 \mathrm{ml}$ of growth medium with or without NGF. At various times, a coverslip was dipped briefly three times into the sucrose/potassium phosphate/glyoxylic acid solution ( $\mathrm{pH} 7.4)$, air-blown dry, mounted on glass slides with $16 \%$ (w/v) Gelvatol 20-30 (Feramisco and Blose, 1980), covered with a light mineral oil, and heated at $95^{\circ} \mathrm{C}$ for $3 \mathrm{~min}$. The slides were examined using a Zeiss Photomicroscope III with epiillumination and $\mathrm{a} \times 63 / 1.4$ planapo oil immersion lens. The excitation range was 390 to $440 \mathrm{~nm}$ and the emission range was 450 to $490 \mathrm{~nm}$.

Labeling of cellular and secreted proteins. Newly 
synthesized cellular and secreted proteins were labeled using a modification of the procedure described by Savion and Gospodarowicz (1980). Briefly, culture dishes (35 $\mathrm{mm}$ ) were washed two times with methionine-free RPMI 1640 and then incubated at $37^{\circ} \mathrm{C}$ for $48 \mathrm{hr}$ (days 3 to 5) in the presence of $1 \mathrm{ml}$ of methionine-free RPMI 1640 supplemented with $1 \%$ horse serum, $2 \mathrm{~mm}$ glutamine, $50 \mu \mathrm{g} / \mathrm{ml}$ of Garamycin, 100 units $/ \mathrm{ml}$ of penicillin, $100 \mu \mathrm{g} / \mathrm{ml}$ of streptomycin, $10 \mu \mathrm{M} \mathrm{L}$-methionine, and 10 $\mu \mathrm{l}$ of $\left.\mathrm{L}-{ }^{[35} \mathrm{S}\right]$ methionine ( 60 to $70 \mu \mathrm{Ci} /$ dish). Monolayers then were washed three times with cold $\left(4^{\circ} \mathrm{C}\right) \mathrm{PBS}$ and lysed immediately with $100 \mu$ l of cell lysis buffer containing $9.5 \mathrm{M}$ urea, $2 \%(\mathrm{w} / \mathrm{v})$ Nonidet $\mathrm{P}-40,2 \%$ Ampholine (pH range 3.5 to 10 ), and $5 \% \beta$-mercaptoethanol. Lysates were stored at $-70^{\circ} \mathrm{C}$ and analyzed by double gel electrophoresis.

Synthesis of secreted proteins was analyzed in cultures 6 days after plating. Cultures were washed as described above and then incubated in $0.7 \mathrm{ml}$ of methionine-free RPMI 1640 with $2 \mathrm{mM}$ glutamine and $7 \mu \mathrm{l}$ of $\mathrm{L}-\left[{ }^{35} \mathrm{~S}\right]$ methionine ( 45 to $50 \mu \mathrm{Ci} / \mathrm{dish})$ for $6 \mathrm{hr}$ at $37^{\circ} \mathrm{C}$. The medium was collected and centrifuged to remove cellular debris, and the supernatant was recovered and frozen for storage. Samples were analyzed by sodium dodecyl sulfate-polyacrylamide slab gel electrophoresis.

Aliquots of the cell lysate or culture supernatant were used to measure trichloroacetic acid-precipitable radioactivity.

Double gel electrophoresis. Separation of cellular proteins was done by two-dimensional polyacrylamide gel electrophoresis (O'Farrell, 1975; O'Farrell et al., 1977). Proteins were separated according to their isoelectric point in the first dimension and according to their molecular weight in the second dimension. An equal number of counts per min of [ $\left.{ }^{35} \mathrm{~S}\right]$ methionine-labeled protein (but varying volumes of cell lysate) from samples to be compared were applied to a set of cylindrical nonequilibrated $\mathrm{pH}$ gradient gels followed by electrophoresis toward the cathode for $4 \mathrm{hr}$ at $450 \mathrm{~V}$. The isoelectric focusing gel was extruded into SDS sample buffer (10\% glycerol, $5 \%$ $\beta$-mercaptoethanol, 2.3\% SDS, and $0.065 \mathrm{~m}$ Tris- $\mathrm{HCl}, \mathrm{pH}$ 6.8 ), equilibrated in this buffer for $2 \mathrm{hr}$, and then loaded onto an exponential gradient ( 10 to $16 \%$ ) polyacrylamide slab gel. The slab gels were run at constant current $(20$ $\mathrm{mA})$ for about $4 \mathrm{hr}$. The gels were stained with $0.1 \%$ Coomassie blue in 50\% TCA, destained in 7\% acetic acid, dried, and exposed for the same length of time to NoScreen Kodak NS-2T x-ray film (Eastman Kodak, Rochester, NY). The $\mathrm{pH}$ value of the isoelectric focusing gels was measured using a parallel gel. Gel segments of 0.5 $\mathrm{cm}$ were soaked in $2.0 \mathrm{ml}$ of degassed water for $1 \mathrm{hr}$. The $\mathrm{pH}$ value of this eluant then was determined with a $\mathrm{pH}$ meter. The pattern of cellular proteins of each sample was determined by at least three independent electrophoretic trials. The fluctuation in the amount of individual peptides was assayed by comparing the intensity of these individual peptide spots with those of other spots in the vicinity.

Analysis of secreted proteins by slab gel electrophoresis. Aliquots of medium containing equal amounts of $\left[{ }^{35} \mathrm{~S}\right]$ methionine-labeled material were mixed with an equal volume of a sample buffer (double strength) com- posed of $15 \%$ glycerol, $2 \%$ SDS, $75 \mathrm{~mm}$ Tris- $\mathrm{HCl}(\mathrm{pH} 6.8)$, $2 \mathrm{mM}$ phenylmethylsulfonyl fluoride, $2 \mathrm{mM}$ EDTA, $1 \mathrm{mM}$ $N$-ethylmaleimide, and $1 \mathrm{~mm}$ iodoacetic acid. The samples were boiled for 2 min to denature nucleic acids and proteins. Samples were applied to an exponential gradient (5 to $16 \%$ ) polyacrylamide slab gel with a $3 \%$ stacking gel (Laemmli, 1970). The slab gels were run at $20 \mathrm{~mA}$ constant current for about $4 \mathrm{hr}$. After electrophoresis, the slab gels were fixed and stained with $0.1 \%$ Coomassie blue in $50 \%$ TCA, followed by destaining in $7 \%$ acetic acid. The slab gels then were dried and subjected to autoradiography on Kodak x-ray film.

\section{Results}

Adhesion of PC12 cells as a function of time and substratum. The time course of attachment of freshly trypsinized PC12 cells to plastic versus collagen- or ECMcoated tissue culture dishes is shown in Figure 1. Less than $5 \%$ of the seeded cells attached to tissue culture dishes over a $24-\mathrm{hr}$ period. When cells were seeded on

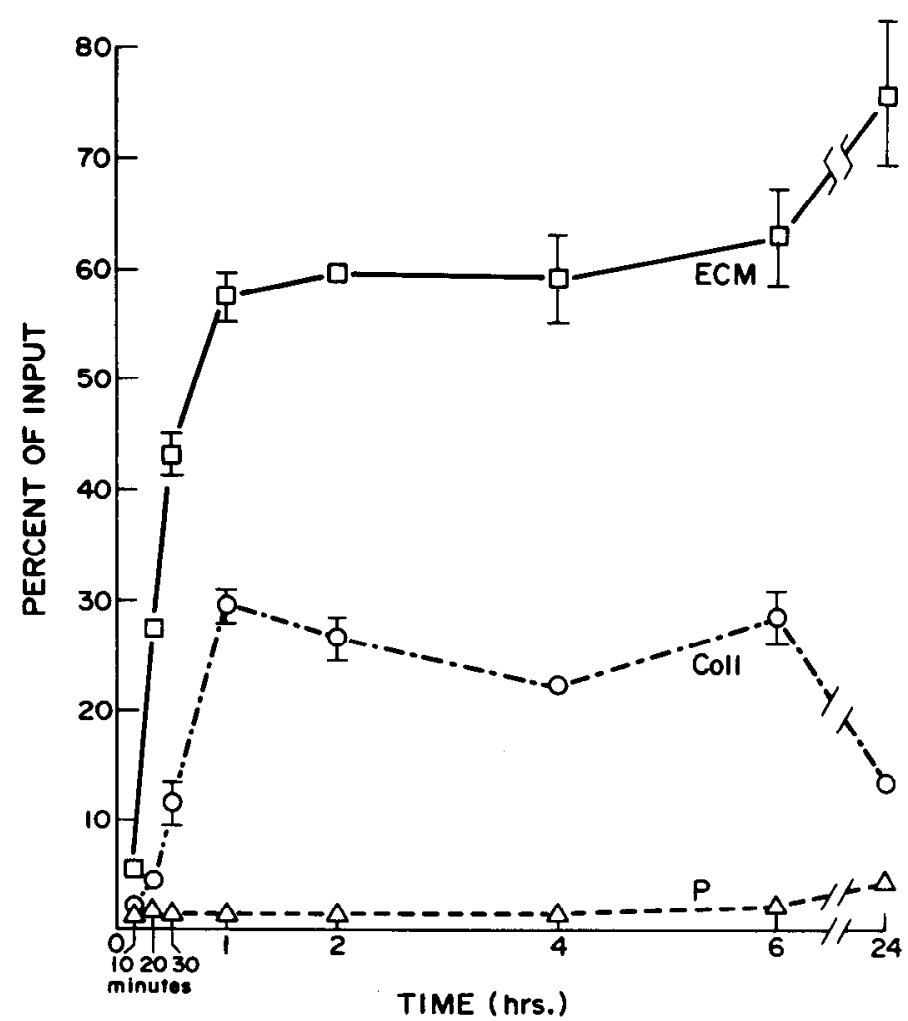

Figure 1. Attachment of PC12 cells to plastic-, collagen-, or ECM-coated dishes. Cells were trypsinized to a cell suspension which was greater than $90 \%$ single cells. The cells were suspended in growth medium at 188,000 cells $/ 2 \mathrm{ml} / 35-\mathrm{mm}$ dish. Unattached or loosely attached cells were suspended and removed by washing and aspiration. Attached cells from duplicate plates were released from the dish with STV solution and counted twice in a Coulter counter. The results are expressed as the mean percentage of the number of input cells which attached to the dish. Cells were plated onto tissue culture dishes $(P, \triangle)$, collagen-coated tissue culture dishes (Coll, $\bigcirc)$, or ECMcoated tissue culture dishes $(E C M, \square)$. The standard deviation did not exceed $10 \%$ of the mean if the percentage of input was greater than $6 \%$. The absence of bars indicates that the standard deviation is less than the size of the symbol. 
collagen-coated dishes, within $1 \mathrm{hr}, 30 \%$ were firmly attached to the collagen. The number of attached cells did not change appreciably during the following $5 \mathrm{hr}$. However, by $24 \mathrm{hr}$, it dropped to $15 \%$, indicating that some cells which initially attached firmly to the collagencoated dishes were later released into the media. When cells were seeded on ECM-coated dishes, they adhered rapidly and efficiently. Within $20 \mathrm{~min}$ of incubation, almost $30 \%$ of the cells were attached, and within $1 \mathrm{hr}$, the number of attached cells reached $58 \%$. Although there was no appreciable change in the number of attached cells during the next $5 \mathrm{hr}$, by $24 \mathrm{hr}$, as many as $80 \%$ of the seeded cells were firmly attached to the substratum.

The morphological appearance was a function of the substratum and of time in culture (Fig. 2). Cells seeded on collagen-coated dishes had, after $10 \mathrm{~min}$ of incubation, the morphological appearance of small, rounded, phasebright cells (Fig. 2A). By $60 \mathrm{~min}$, a few cells had flattened, but the majority of them were still rounded (Fig. $2 B$ ). By $24 \mathrm{hr}$, although the number of flattened cells had increased, most of the adhering cells were still rounded (Fig. $2 C$ ). In contrast, when cells were seeded on ECM, although, by $10 \mathrm{~min}$, most of the cells were rounded, a few flattened cells could be observed (Fig. 2D). By 60 min, most of the cells were flattened (Fig. $2 E$ ). A similar morphological appearance was observed after $24 \mathrm{hr}$ (Fig. $2 F$ ). At that time, it also can be observed that many cells adhering to the ECM have visible neurite outgrowths (Fig. $2 F$ ).

Over the course of several days, it also was observed that, on both plastic and collagen-coated dishes, PC12 cells seeded as single cells tended to aggregate, forming clumps of cells. In contrast, cells maintained on ECMcoated dishes tended to remain as flattened individual cells (D. K. Fujii, S. L. Massoglia, N. Savion, and D. Gospodarowicz, unpublished observation).

The effect of $7 \mathrm{~S}$ NGF, dbcAMP, and potassium ions on PC12 cell attachment to collagen versus ECM-coated dishes also was analyzed. Seeding PC12 cells onto ECMcoated dishes in the presence of 7 S NGF $(3 \mu \mathrm{g} / \mathrm{ml})$, dbcAMP $(1 \mathrm{~mm})$, or $\mathrm{K}^{+}(55 \mathrm{~mm})$ did not affect either
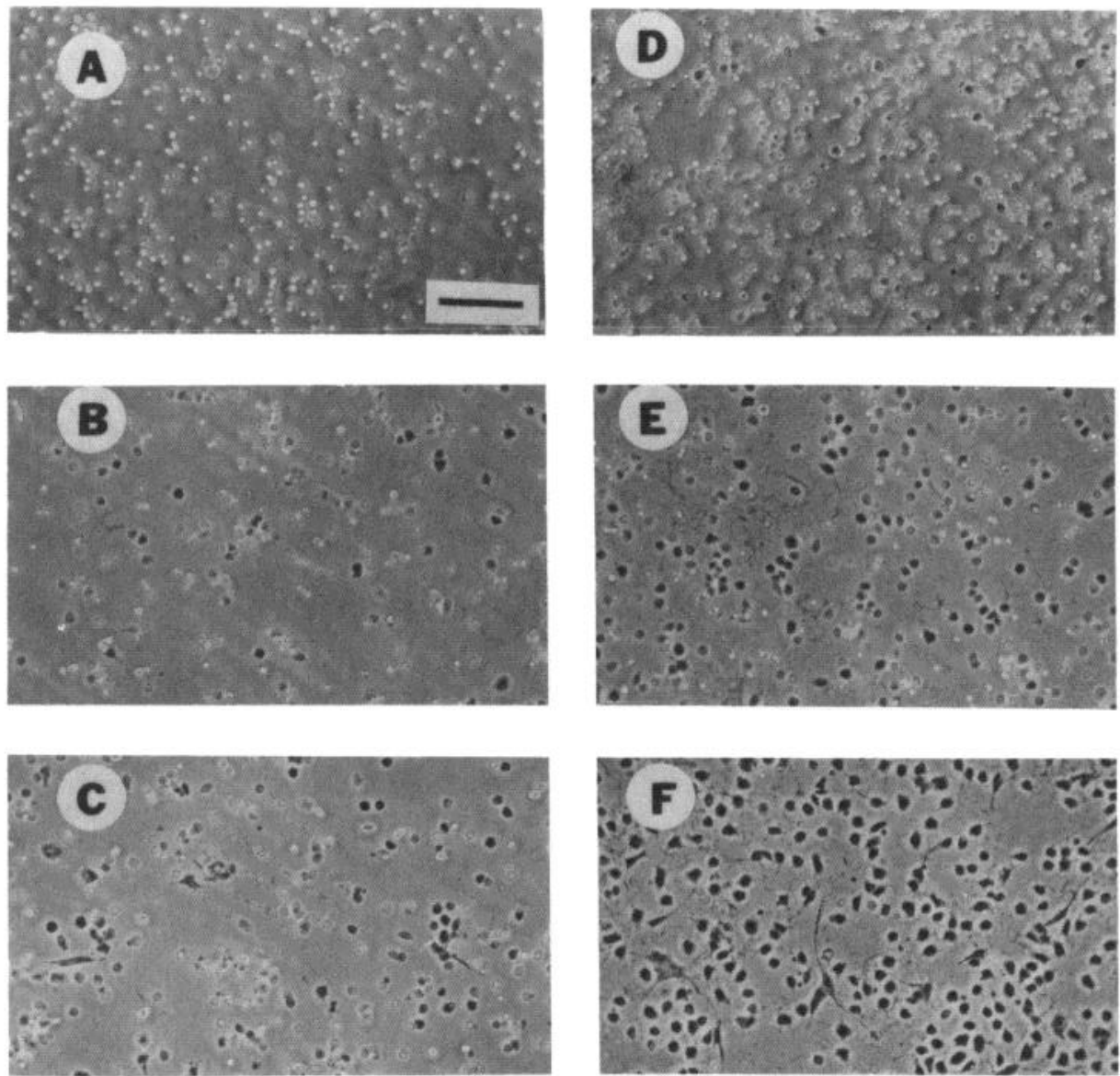

Figure 2. Morphological appearance of $\mathrm{PC} 12$ cells at various times after plating on collagen- or ECM-coated dishes. Cells were plated onto collagen- ( $A$ to $C$ ) or ECMcoated $(D$ to $F)$ tissue culture dishes at $10 \mathrm{~min}(A$ to $D)$ and $1(B$ and $E)$ and $24 \mathrm{hr}(C$ and $F$ ). Phase contrast microscopy was used. Bar, $100 \mu \mathrm{m}$. The pictures taken at 10 $\min (A$ and $D)$ were done before washing and aspiration to remove unattached cells. Others were taken after washing and aspiration. Cells plated onto plastic dishes were similar in morphology for the first $6 \mathrm{hr}$ to those plated on collagen-coated dishes for 10 $\min (A)$. At $24 \mathrm{hr}$, their morphology was like that of cells plated on collagen for $1 \mathrm{hr}$ (B). 
their rate of attachment or the attachment efficiency. Overnight pre-exposure of PC12 cultures maintained on plastic to NGF only slightly enhanced the ability of the trypsinized cell maintained in the presence of NGF to attach to collagen-coated dishes (10 to 15\%) or ECMcoated dishes (5 to $10 \%$ ) after a 1 -hr incubation (D. K. Fujii, S. L. Massoglia, N. Savion, and D. Gospodarowicz, unpublished results). Thus, cell attachment to ECM is nearly optimal, when compared to plastic and collagencoated dishes, and cannot be improved much by addition of various factors known to induce neurites from $\mathrm{PC} 12$ cells.

Neurite outgrowth on ECM as a function of time and NGF exposure. PC12 cells, like primary sympathetic neurons, exhibit neurite outgrowth when exposed to NGF (Greene and Tischler, 1976). Therefore, we have analyzed the ability of cells to initiate neurite outgrowth as a function of the substratum upon which the cells were maintained and as a function of whether cultures were exposed to NGF. When cells were plated onto ECMcoated dishes, $52 \%$ of the cells had neurites by $48 \mathrm{hr}$ (Fig. 3). This morphological differentiation (Fig. 4, $A$ and $B$ ) was, however, not permanent. After $48 \mathrm{hr}$, the percentage of cells expressing neurites started to decrease. Neurites were seen to retract and were not pinched off from the cell body so that, between days 5 and 10, nearly all of the cells in cultures maintained in the absence of NGF were without neurites.

In contrast, when $7 \mathrm{~S} \mathrm{NGF}(3 \mu \mathrm{g} / \mathrm{ml})$ was present, nearly $74 \%$ of the cells exhibited prominent neurite outgrowth within $48 \mathrm{hr}$ (Figs. 3 and $4, C$ and $D$ ). As time progressed, both the length and number of their neurites extending from cell bodies increased in cultures exposed to NGF (Fig. 4, $E$ and $F$ ).

It was reported by Greene and Tischler (1976) that the NGF-induced neurites of $\mathrm{PC} 12$ cells maintained on rat tail collagen-coated dishes retract quickly $(75 \%$ decrease with $24 \mathrm{hr}$ ) once NGF was no longer present in the medium. In contrast, the rate of retraction of NGF-induced neurites of cells maintained on ECM-coated dishes was much slower. Even 7 days after the removal of NGF, numerous neurites extending from the cells maintained on ECM-coated dishes could be observed (Fig. 4, $G$ and $H)$.

Neurite outgrowth in the absence of NGF also was observed on an ECM produced by bovine vascular endothelial cell cultures and had a time course similar to that observed on the corneal ECM (D. K. Fujii, S. L. Massoglia, N. Savion, and D. Gospodarowicz, unpublished results).

Morphological appearance and catecholamine distribution in neurite outgrowths present in PC12 cultures maintained on ECM-coated dishes and exposed or not to NGF. When the morphological appearance of neurites in cultures maintained on ECM-coated dishes and exposed or not to NGF was compared, it was observed that, in both cases, they had the same morphological appearance (Fig. $4, A$ to $D$ ). In both cases, the nerve fibers were very slender $(0.09$ to $1 \mu \mathrm{m}$ in diameter) with varicosities, branching, some fascicles, microspikes (about $0.14 \mu \mathrm{m}$ in diameter), as well as growth cones (Fig. 5). Even after 1 or 2 days in culture, some neurites could have a length greater than $100 \mu \mathrm{m}$. Particularly interesting was the disposition on both sides of some neurites of microspikes, which extended from them and appeared to be "stapling" the neurite to the substratum (Fig. 5). A similar configuration of microspikes or branchlets has been observed by Roberts (1976) for actively growing axons in vivo that move along the inner surface of an epidermal basal lamina. The only difference between 4-day-old cultures maintained in the presence versus absence of NGF was in the higher density of neurites present in the cultures exposed to NGF. This also was reflected by a greater average number of neurite outgrowths per cell, which in some cases, could be as many as 12 neurites (Fig. $4 F$ ).

The continuous and curvilinear appearance of neurites developing on ECM-coated dishes reflected their close association with the substratum. A distinct feature of the morphological appearance of neurites from PC12 cells on collagen-coated dishes in the presence of NGF is that they appear as rectilinear segments (much like lines connecting dots) that attach to the substratum only at points where the direction changes. Poor attachment of neurites between points of contact was indicated by their movement when the medium was disturbed.

The apical cell surface morphology of cells maintained on ECM for 2 days in the presence or absence of NGF

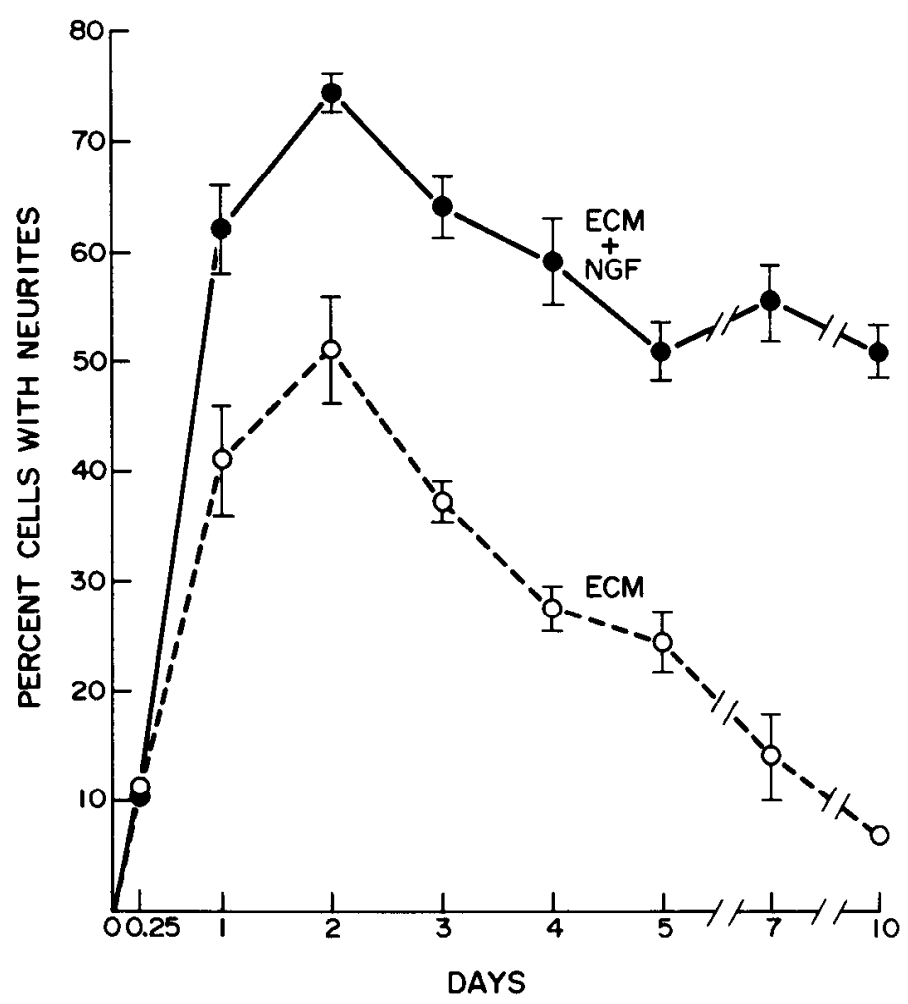

Figure 3. Neurite outgrowth by $\mathrm{PC} 12$ cells on ECM with or without NGF. Cells were dissociated as described in the text and seeded at $5 \times 10^{4}$ cells $/ 35$-mm ECM-coated dish in $2 \mathrm{ml}$ of growth medium with (O) or without (O) NGF. 7 S NGF ( $3 \mu \mathrm{g}$ / $\mathrm{ml}$ ) was added immediately and then every other day, when one-half of the culture medium was replaced with fresh medium. The mean percentage of cells with neurites (three separate determinations $\pm \mathrm{SD}$ ) of the total number of cells is plotted as a function of time. Pictures were taken at approximately the same time every day. 

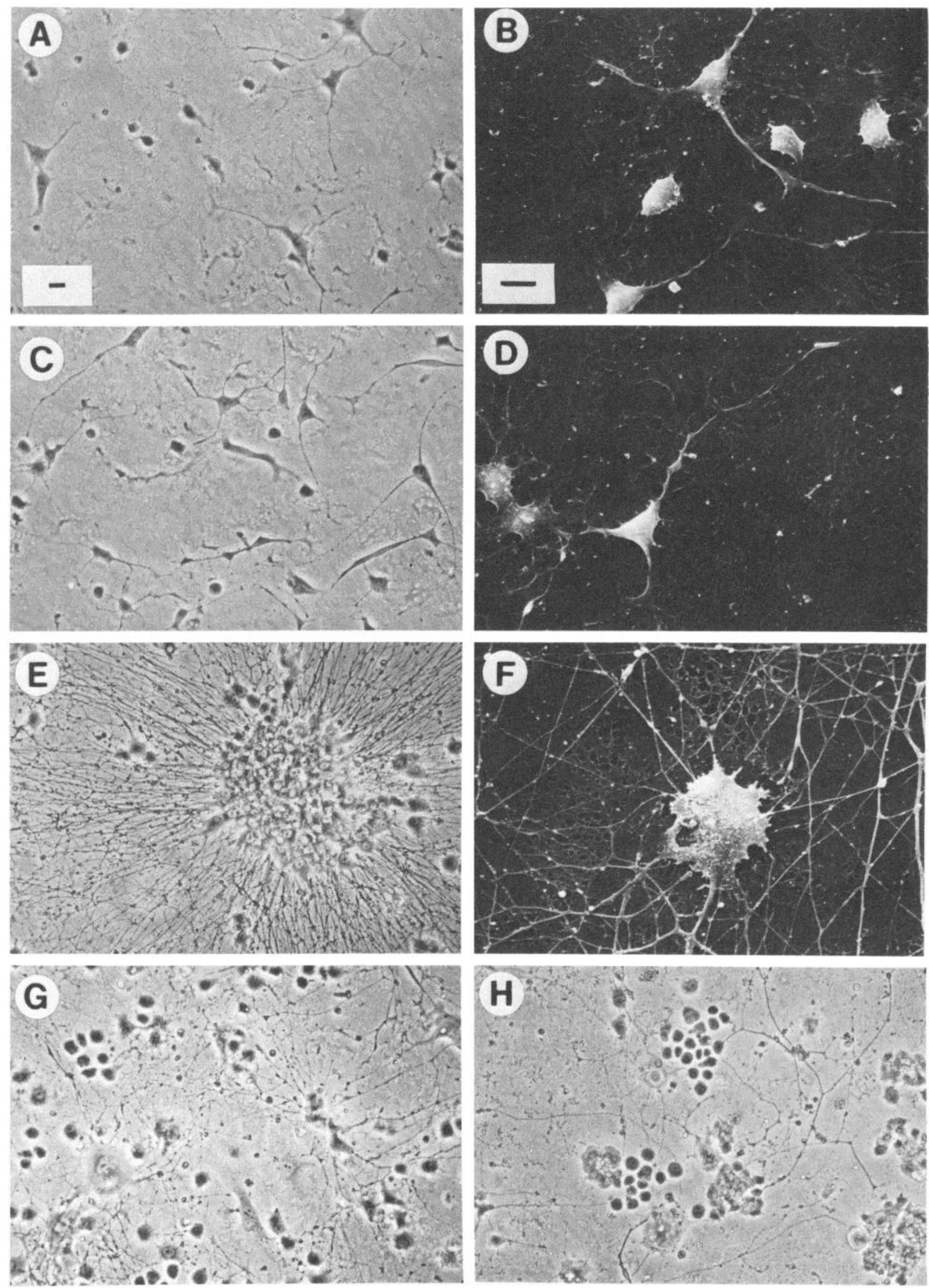

Figure 4. Phase contrast and scanning electron micrographs of PC12 cells on ECM-coated dishes in presence or absence of NGF. $A, C, E, G$, and $H$, Phase contrast photographs of unfixed PC12 cells on ECM-coated dishes. Bar, $20 \mu \mathrm{m} . B, D$, and $F$, Scanning electron micrographs of fixed PC12 cells on ECM-coated dishes. Bar, $10 \mu \mathrm{m}$. A and B, Cells on an ECM-coated dish for 2 days in the absence of NGF. $C$ and $D$, Cells on an ECM-coated dish for 2 days in the presence of $\beta$-NGF (50 ng/ml). $E$ and $F$, Cells on an ECM-coated dish for 13 and 18 days, respectively, with 7 S NGF $(3 \mu \mathrm{g} / \mathrm{ml})$. $G$, PC12 cells on an ECM-coated dish for 7 days in the presence of $7 \mathrm{~S} \mathrm{NGF}(3 \mu \mathrm{g} / \mathrm{ml}) . H$, The same culture of cells as in $G$ but 7 days later in the absence of NGF. 


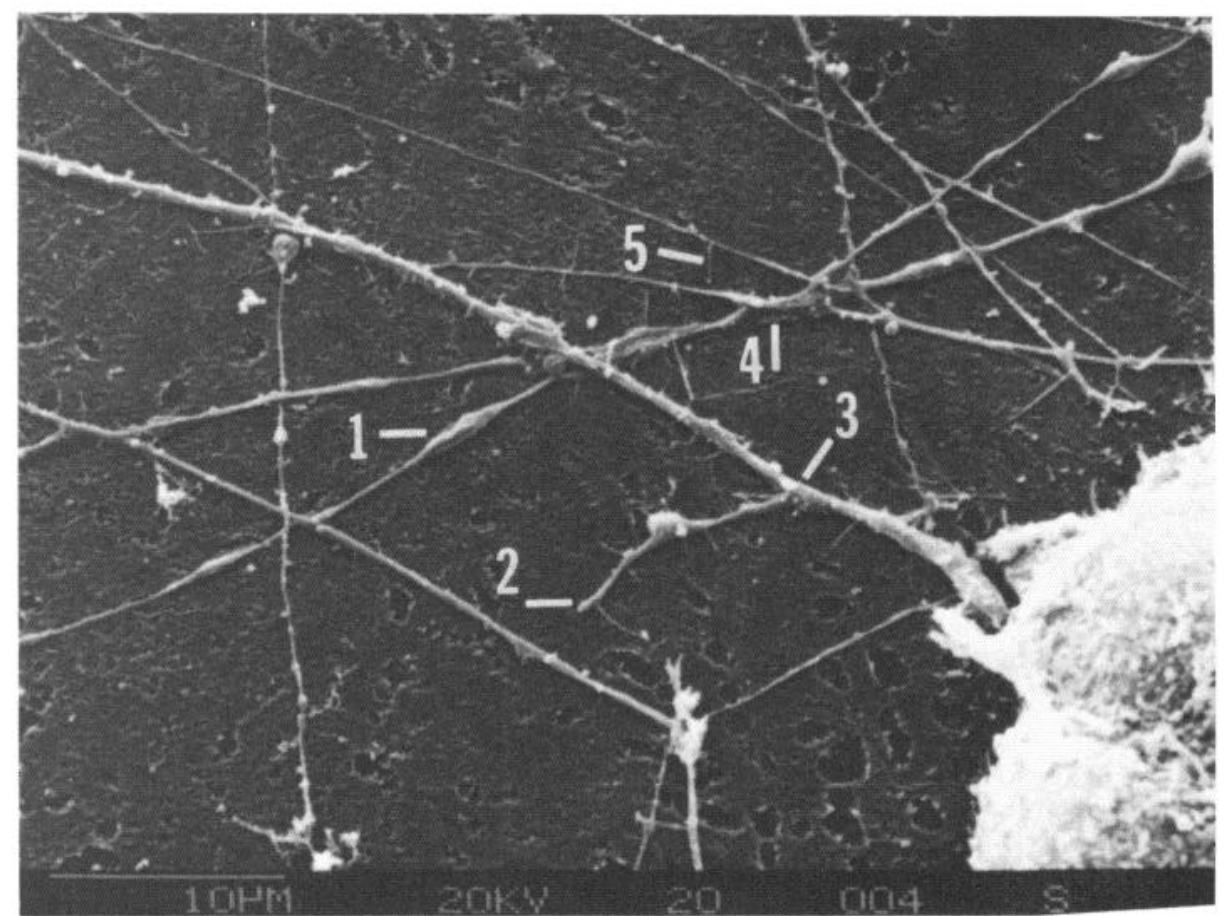

Figure 5. Scanning electron micrograph of PC12 cells on an ECM-coated dish in the presence of $7 \mathrm{~S} \mathrm{NGF}(3 \mu \mathrm{g} / \mathrm{ml})$ for 12 days. Shown here are examples of varicosities (1), a growth cone with a microspike (2), a branching point of a neurite (3), an area of apparent fasciculation (4), and a microspike extending from a neurite (5). Parts of two highly villous cell bodies are in the lower right. The ECM is the granular surface punctuated with holes on which the neurites rest.

was relatively smooth (Fig. $4, B$ and $D$ ), possibly the result of the increased adhesion to the ECM. Cells in the presence of NGF on ECM in time develop a highly villous cell surface (Fig. 5) similar to that reported by Connolly et al. (1979).

Stock cultures of PC12 cells on tissue culture plastic appeared to be morphologically homogeneous. Most cells were in large aggregates, which were either loosely attached to the plastic or floating in the media. In contrast, trypsin-dissociated single cells seeded on ECM-coated dishes initially appeared to be homogeneous, with an occasional $(<1 \%)$ very flat and spread-out cell (Fig. $4 G$ ). However, after about day 8 in culture on ECM, the cells began to multiply (with an average doubling time of 3 to 4 days during their logarithmic growth phase (D. K. Fujii, S. L. Massoglia, N. Savion, and D. Gospodarowicz, unpublished results), a doubling time similar to that reported by Greene and Tischler (1976)) and two other distinct cell populations became evident. One type of cell remained clearly separated from its neighbor, while the other type, composed of (apparently) smaller cells, grew in such tight aggregates that no cell borders were visible under phase contrast microscopy (Fig. $4 H$ ). Cell borders were evident, however, when examined by transmission electron microscopy (D. K. Fujii, S. L. Massoglia, N. Savion, and D. Gospodarowicz, unpublished observations). Cultures always behaved in this manner when maintained on ECM-coated dishes regardless of their passage number. All three cell types emitted neurites in the presence of NGF.

The presence of catecholamines, which was reported previously (Greene and Tischler, 1976), in the cell body and neurites of cells maintained on ECM exposed or not to NGF was indicated by a glyoxylic acid-induced, intense yellow-green fluorescence (Fig. 6). During the first few days, fluorescence can be seen in the cell body and all along the neurite. At later times (after about day 8), in the continued presence of NGF, the fluorescence tended to be localized in the neurites, particularly at the growth cones, branching points, and varicosities, although many cell bodies were fluorescent. As was previously reported (Tischler and Greene, 1978), not every cell was fluorescent regardless of length of time (up to 10 days) in culture or presence of NGF. During a 10-day period, the mean number of fluorescent cells in the absence of NGF was $58.3 \pm 10.5 \%$, while in the presence of NGF, it was 50.4 $\pm 7.0 \%$. On day 10 , the percentage of fluorescent cells was $62.5 \%$ in the absence of NGF and $35.0 \%$ in its presence. A similar decrease in the number of fluorescent cells was observed by Tischler and Greene (1978) for cells exposed to NGF for 2 weeks.

Ultrastructural properties of PC12 cell cultures on ECM-coated dishes in the presence or absence of NGF. When the ultrastructural characteristics of cells cultured for 2 days on ECM-coated dishes and exposed to NGF were compared to those of cultures maintained in the absence of NGF, no striking morphological differences could be observed when cells were viewed by transmission electron microscopy (Fig. 7). In both cases, numerous free ribosomes and mitochondria appear in the perikaryon of the cells and their neurites (Fig. 7, $A$ and $C$ ). Along the plasma membranes of adjacent cells, puncta 

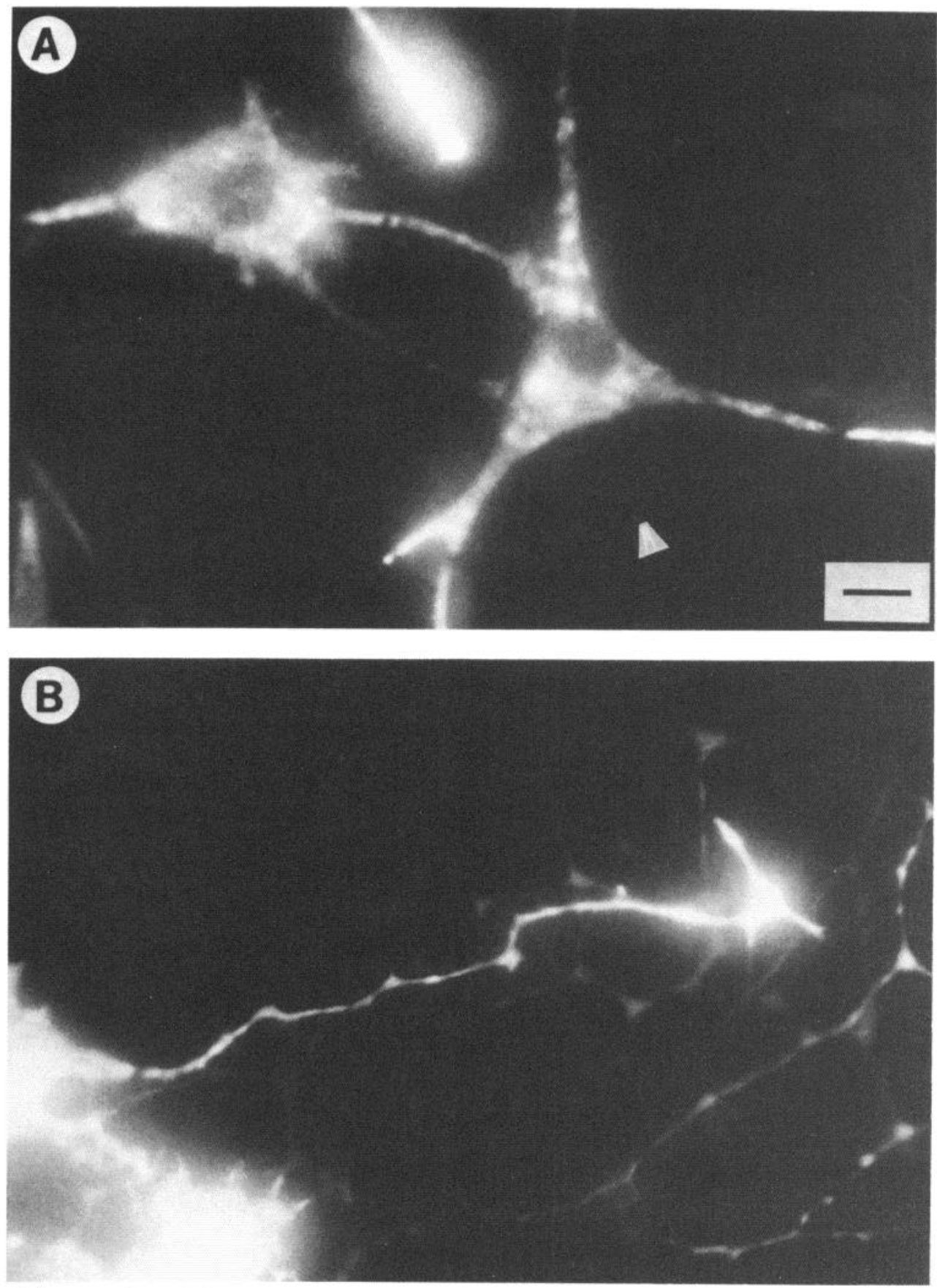

Figure 6. Catecholamine fluorescence of PC12 cells on ECM-coated glass coverslips in the presence or absence of $\beta$-NGF. $A$, Cells on ECM for 2 days without NGF. The arrowhead indicates a nonfluorescent cell. $B$, Cells on ECM for 8 days with $\beta$-NGF (50 ng/ml). Bar, 10 $\mu \mathrm{m}$.

adhaerentia were observed (D. K. Fujii, S. L. Massoglia, N. Savion, and D. Gospodarowicz, unpublished observations). Very dense core vesicles (diameter, $123 \pm 13 \mathrm{~nm}$ ) are found in neurites and along plasma membranes of cells regardless of whether the cells were exposed to NGF (Fig. 7, $A$ and $B$ ). A somewhat lighter, granular core vesicle also was observed, usually in the presence of the darker core vesicles. These lighter core vesicles had a mean diameter of $107 \pm 14 \mathrm{~nm}$ in the absence of NGF and $114 \pm 13 \mathrm{~nm}$ in the presence of NGF (Fig. 7, $A$ and $B)$. These vesicles closely resemble those found in rat adrenal medulla cells (Millar and Unsicker, 1981) and in PC12 cells (Tischler and Greene, 1978). No clear, small, round vesicles (20 to $70 \mathrm{~nm}$ in diameter) were observed. Neurofilaments and microtubules were observed in the perikaryon of cells and in neurite outgrowths present in cultures exposed or not to NGF (Fig. 7B). Some microtubules appear to follow a helical path within the neurite (Fig. 7B) (Johnston and Wessels, 1980). Microspikes were observed to extend from neurites and from the end of a growth cone (Fig. $7 \mathrm{C}$ ).

Effect of various agents, conditions, and metabolic 

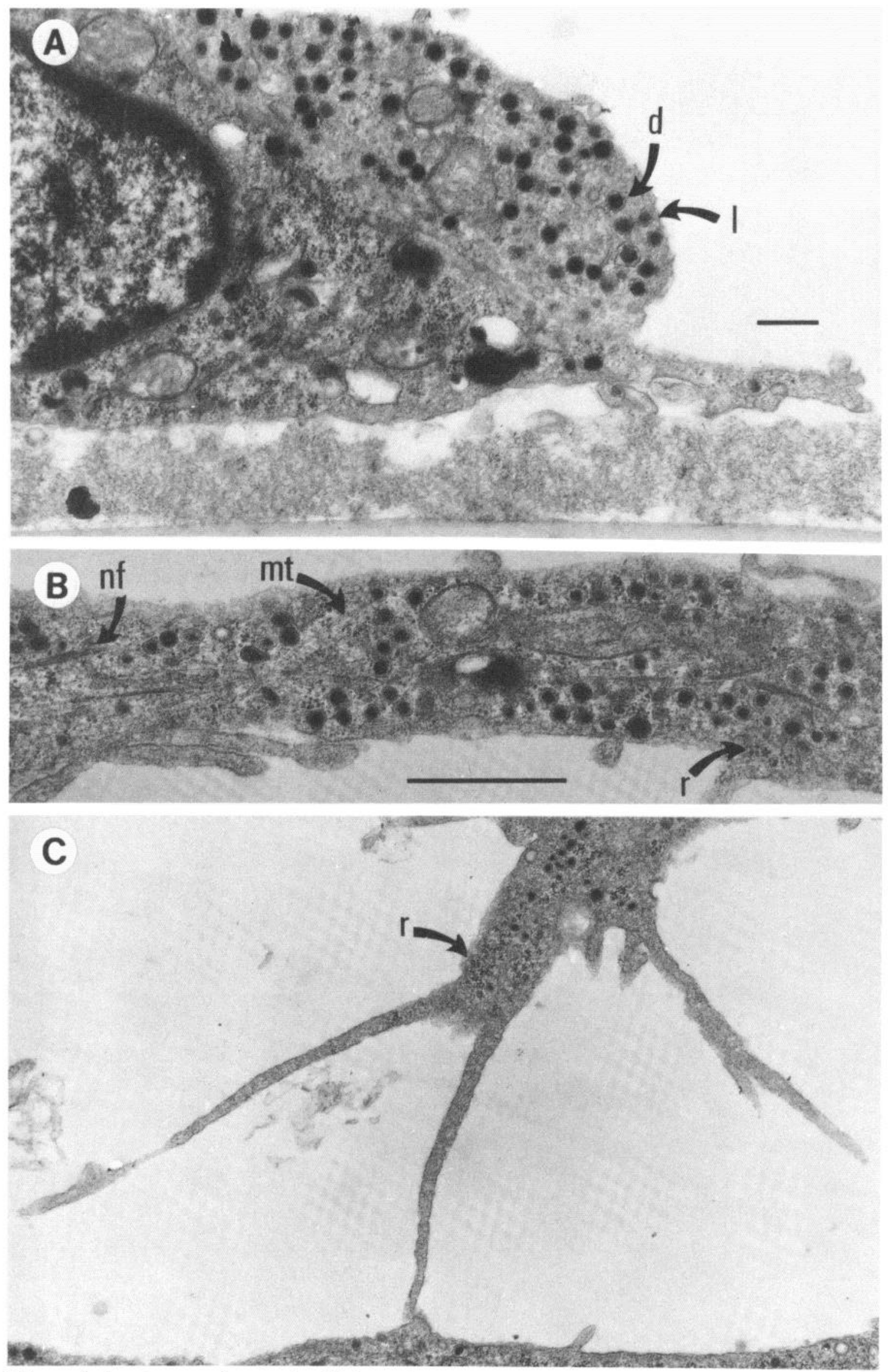

Figure 7. Transmission electron micrographs of PC12 cells on an ECM-coated dish in the presence or absence of NGF 2 days after seeding. $A$, Cells in the presence of $7 \mathrm{~S} \mathrm{NGF}(3 \mu \mathrm{g} / \mathrm{ml})$ showing a cell body in contact with the ECM coating with many free ribosomes and a neurite in cross-section containing many dark $(d)$ and lighter $(l)$ core vesicles. Bar, $1 \mu \mathrm{m}$. $B$, Cells in the absence of NGF showing a neurite containing dark and lighter core vesicles, microtubules $(m t)$ and neurofilaments $(n f)$. $C$, The end of a neurite growth cone with microspikes containing ribosomes $(r)$ and vesicles. Bar, $1 \mu \mathrm{m}$. 
inhibitors on neurite outgrowth by PC12 cultures maintained on ECM. It was reported previously that dbcAMP and high concentrations of potassium ion increased neurite outgrowth by $\mathrm{PC} 12$ cells maintained on tissue culture dishes (Schubert et al., 1978; Gunning et al., 1981). We also found that dbcAMP (1 mM), $\mathrm{K}^{+}(55 \mathrm{~mm})$, as well as serum-free conditions (Schubert et al., 1971; Haffke and Seeds, 1975) all enhanced the outgrowth and survival of neurites on ECM in a manner similar to NGF (Table I).

For some neuroblastomas, neurite formation can be induced by actinomycin D or cytosine arabinoside (Schubert et al., 1971; Haffke and Seeds, 1975). When both actinomycin $\mathrm{D}(1$ or $10 \mu \mathrm{M})$ and cytosine arabinoside $(1 \mu \mathrm{M})$ were tested for their ability to stimulate neurite outgrowth from cells maintained on ECM-coated dishes (Table II), it was observed that neither of these agents resulted in the promotion of neurite outgrowth, a finding consistent with previous observations (Greene and Tischler, 1976).

Cycloheximide, an inhibitor of protein synthesis, completely inhibited neurite outgrowth (Table II). A similar effect was noted for cells on ECM-coated dishes exposed to cobalt ions (a calcium ion antagonist) (Table II). However, under the above conditions that inhibited neurite outgrowth, there was also a decreased survival and flattening of cells (many cells attached but remained

\section{TABLE I}

Effect of various agents or conditions on the ability of ECM-coated dishes to support PC12 neurite outgrowth

Cells ( 4 to $5 \times 10^{4}$ cells) were plated onto an ECM-coated dish (35 $\mathrm{mm}$ ) in $2 \mathrm{ml}$ of growth medium or serum-free medium. Agents were added just after plating. Cells were washed three times in serum-free medium before plating in serum-free medium after using growth medium to neutralize the trypsin used to dissociate the cells.

\begin{tabular}{llcc}
\hline & Concentration & \multicolumn{2}{c}{ Percent Cells with Neurites } \\
\cline { 3 - 4 } & & Day 1 & Day 4 \\
\hline ECM & & 40.9 & 19.1 \\
dbcAMP & $1 \mathrm{mM}$ & 71.5 & 77.1 \\
$\mathrm{~K}^{+}$ & $55 \mathrm{mM}$ & 30.3 & 60.8 \\
No serum & & 30.7 & $68.0^{a}$ \\
7 S NGF & $3 \mu \mathrm{g} / \mathrm{ml}$ & 58.0 & 55.0 \\
\hline
\end{tabular}

"Actual day, day 5.

\section{TABLE II}

Effect of metabolic inhibitors and anti-NGF serum on the ability of ECM-coated dishes to support PC12 neurite outgrowth

Cells were plated and agents were added as described in Table I. One day after plating, cultures were scored for the percentage of cells bearing neurites, as described in the text. Cells plated onto ECM-coated dishes in growth medium in the absence of any other exogenous agents were the control and set to $100 \%$. The percentage of control is relative to the individual ECM control experiments and represents the average of two experiments. The mean percentage of cells with neurites on day 1 in 11 experiments was $37.8 \pm 2.4 \%$.

\begin{tabular}{llc}
\hline & Concentration & Percent Control \\
\hline ECM & & 100 \\
Actinomycin D & 1 or $10 \mu \mathrm{M}$ & 0 \\
Ara C & $1 \mu \mathrm{M}$ & 43.0 \\
Cycloheximide & $0.1 \mathrm{mM}$ & 0 \\
Cobalt & $2 \mathrm{mM}$ & 0 \\
Anti-NGF & $200 \times$ & 158.5 \\
\hline
\end{tabular}

rounded) whether the inhibitor was added just after the plating of the cells or as late as $5.5 \mathrm{hr}$ after plating, by which time most cells had flattened.

Effect of NGF antiserum pretreatment of ECM-coated dishes on their ability to support neurite outgrowth in PC12 cultures not exposed to NGF. One possible explanation for the ability of ECM-coated dishes to support and promote neurite outgrowth could be the presence of a structural determinant similar to that of $\beta$-NGF. Equally possible is that NGF itself could be adsorbed from the serum onto the ECM. If either possibility were the case, then pretreatment of ECM-coated dishes with NGF antibodies, which have been shown to be capable of neutralizing NGF's biological effect, should block neurite outgrowth on ECM. The speed at which neurites develop on ECM is quite similar to that described by Greene (1977) for neurite regeneration by $\mathrm{PC} 12$ cells previously exposed to NGF. Using Greene's criteria (Greene, 1977) for activity and calculation of the specific activity of $\beta$-NGF, one could estimate the amount of NGF which should be present within the ECM to induce such an effect. Typically, in 24 to $48 \mathrm{hr}$, about $50 \%$ of the cells on ECM have neurites. This would correspond to 1 unit of $\beta-\mathrm{NGF} / \mathrm{ml}$ or $0.25 \mathrm{ng}$ of $\beta-\mathrm{NGF} / \mathrm{ml}$. When ECMcoated dishes covered with $1 \mathrm{ml}$ of growth medium were exposed overnight to a rabbit anti-mouse NGF antiserum capable of neutralizing $50 \mathrm{ng}$ of $\beta$-NGF (a 200 -fold excess), they were still capable of supporting neurite outgrowth with at least the same efficiency as untreated ECM even in the continued presence of NGF antibodies (Table II). It is therefore highly unlikely that the ability of the ECM to support neurite outgrowth could be due to adsorbed NGF or to an NGF-like determinant present within the ECM. A negative result with even a polyclonal antiserum is not a conclusive demonstration of absence, however.

Ability of various artificial substrata to support neurite outgrowth by PC12 cells in the absence of NGF When various agents used to coat plastic dishes were tested for their ability to support neurite outgrowth 1 day after seeding and compared to ECM-coated dishes, none of the agents, with the exception of bovine skin collagen (a mixture of types I and III), supported appreciable neurite outgrowth (Table III). Although bovine skin collagen could support short neurite outgrowth from about 10 to $15 \%$ of the cells $24 \mathrm{hr}$ after seeding, virtually all neurites were retracted by $48 \mathrm{hr}$. Neurite outgrowth on collagen-coated dishes did not always occur (2 of 4 experiments). Neurite initiation in those experiments may have been the result of using a stock culture with a larger percentage of the flat cell variant which arises spontaneously. Gelatin-coated dishes did not support neurite outgrowth. Human fibronectin coated onto plastic, poly-D-lysine-coated dishes, or collagen-coated dishes and poly-D-coated dishes alone were ineffective (Table III). Bovine plasma fibronectin coated on dishes in buffers of $\mathrm{pH} 6.0,6.5$, and 7.2 as described by Akers et al. (1982) was also ineffective in supporting neurite outgrowth even in the absence of serum (D. K. Fujii, S. L. Massoglia, N. Savion, and D. Gospodarowicz, unpublished results).

Conditioned media from bovine vascular and corneal 
endothelial cell cultures, which had been shown in previous studies (Vlodavsky and Gospodarowicz, 1981) to contain both fibronectin and laminin, as well as various types of procollagen and proteoglycans, also were tested for their ability to induce neurite outgrowth. Plates were first coated with poly-D-lysine and then exposed to conditioned medium overnight in order to adsorb on the plastic surface the various components present in the conditioned media in a manner similar to that described by Collins (1978b). When such coated plates were tested for their ability to support neurite outgrowth, no significant stimulation was observed (Table III).

Effect of enzymatic and chemical treatment of ECMcoated dishes on PC12 cell attachment and neurite outgrouth. In order to elucidate the nature of the factor(s) present within the ECM which is involved in supporting neurite outgrowth, ECM-coated dishes were first submitted to various enzymatic and chemical treatments. Treatments with trypsin, chymotrypsin, or a relatively nonspecific collagenase all inhibited neurite outgrowth by greater than $80 \%$ (Table IV). Trypsin and chymotrypsin left the ECM visibly intact, while collagenase treatment destroyed it. Cell attachment to trypsintreated ECM was approximately 10 to $20 \%$ less than the untreated ECM control over a 2 -hr period (D. K. Fujii, S. L. Massoglia, N. Savion, and D. Gospodarowicz, unpublished results). Thus, the reduced ability of ECM to support neurite outgrowth after protease or collagenase treatment could result, in part, from a decreased cellular adhesion to the ECM, since when observed by phase contrast microscopy, the cells were rounded, instead of assuming the flattened morphology observed on untreated ECM. In order to evaluate the relative importance of intra- and interdisulfide bridges present within the ECM for neurite outgrowth, ECM-coated dishes were exposed to 0.1 м DTT, which resulted in a $27 \%$ reduction in neurite outgrowth (Table IV).

In order to evaluate the involvement of glycosaminoglycans present within the ECM in promoting neurite outgrowth, ECM-coated dishes were exposed to either 4

TABLE III

Comparison of the ability of various substrates to support PC12 cell neurite outgrowth

Culture dishes were coated as described in the text. Cells were plated and scored after $24 \mathrm{hr}$ as in Table II.

\begin{tabular}{llc}
\hline & \multicolumn{1}{c}{ Concentration } & Percent Control \\
\hline $\begin{array}{l}\text { ECM } \\
\text { Bovine skin collagen }\end{array}$ & $10 \mu \mathrm{g}$ & 100 \\
$\quad$ type I & $0.2 \%$ & 30.4 \\
$\begin{array}{l}\text { Gelatin } \\
\text { Fibronectin }\end{array}$ & $20 \mu \mathrm{g}$ & 0 \\
Bovine skin collagen + & $10 \mu \mathrm{g}+40 \mu \mathrm{g}$ & 0 \\
$\quad$ fibronectin & $1 \mathrm{mg} / \mathrm{ml}$ & 0 \\
$\begin{array}{l}\text { Poly-D-lysine } \\
\text { Poly-1)-lysine }+ \\
\text { fibronectin }\end{array}$ & $40 \mu \mathrm{g}$ & 0 \\
$\begin{array}{l}\text { Poly-D-lysine }+ \\
\quad \text { ABAE' conditioned } \\
\text { medium }\end{array}$ & $1 \mathrm{ml}$ of $1 \times$ & \\
Poly-D-lysine + BCE & & 9.5 \\
$\quad$ conditioned medium & $2 \mathrm{ml}$ of $1 \times$ or $9 \times$ & \\
\hline
\end{tabular}

"ABAF, adult bovine aortic endothelial cell.
TABLE IV

Effect of enzymatic and chemical treatments on the ability of the ECM to support neurite outgrowth by PC12 cells

ECM-coated dishes were treated as described in the text. Cells were plated and scored after $24 \mathrm{hr}$ as described in Table II.

\begin{tabular}{llc}
\hline & \multicolumn{1}{c}{ Concentration } & Percent Control \\
\hline ECM & & 100 \\
Trypsin & $0.1 \%$ & 8.2 \\
Chymotrypsin & $0.1 \%$ & 10.3 \\
Collagenase & $0.1 \%$ & 1.1 \\
$\mathrm{DTT}$ & $0.1 \mathrm{M}$ & 73.0 \\
$\mathrm{GuHCl}$ & $4 \mathrm{M}$ & 15.2 \\
$\mathrm{NH}_{4} \mathrm{OH}$ & $14 \mathrm{M}$ & 0 \\
$\mathrm{HNO}_{2}$ & $2.5 \%, \mathrm{pH} 3.26$ & 8.4 \\
Chondroitinase $^{\mathrm{ABC}}$ & $1 \mathrm{unit}$ & 78.5 \\
\hline
\end{tabular}

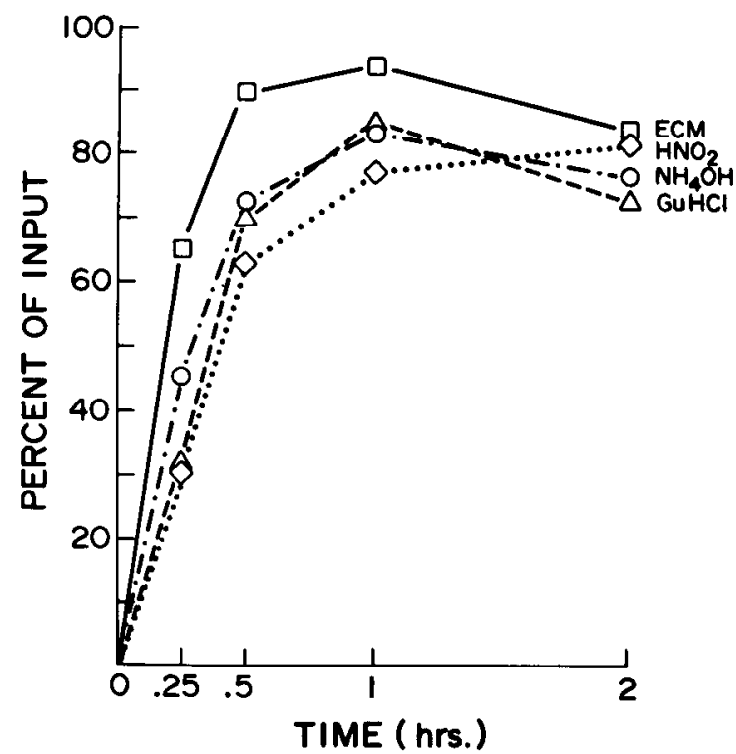

Figure 8. Attachment of PC12 cells to ECM-coated dishes treated with $\mathrm{NH}_{4} \mathrm{OH}, \mathrm{GuHCl}$, or $\mathrm{HNO}_{2}$. Cells were plated $(400,000$ cells $/ 2 \mathrm{ml} / 35-\mathrm{mm}$ dish $)$ as in Figure 1. ECM-coated dishes were treated with 14 м $\mathrm{NH}_{4} \mathrm{OH}(\mathrm{O}), 4 \mathrm{~m} \mathrm{GuHCl}(\triangle)$, $2.5 \% \mathrm{HNO}_{2}(\diamond)$, or untreated ECM $(\square)$ as described in the text. The standard deviation did not exceed $10 \%$ of the mean.

M GuHCl, $14 \mathrm{M} \mathrm{NH}_{4} \mathrm{OH}$, or $2.5 \% \mathrm{HNO}_{2}$. While treatment of $\mathrm{ECM}$ with $\mathrm{GuHCl}$ or strong bases is known to remove most of the glycosaminoglycans (Sajdera and Hascall, 1969), as well as the nondisulfide-bonded proteins or glycoproteins present in the matrix, $\mathrm{HNO}_{2}$ specifically cleaves the glycosaminoglycan heparan sulfate at the glycosidic bond adjacent to $\mathrm{N}$-sulfate group (Kosher and Searls, 1973; Cifonelli, 1968; Castellani et al., 1970). Pretreatment of ECM-coated dishes with $\mathrm{GuHCl}$ reduced neurite outgrowth by $85 \%$ ('Table IV), while exposure to $\mathrm{NH}_{4} \mathrm{OH}$ stopped it completely. This suggests that the active component of the ECM involved in neurite outgrowth is extracted or inactivated by exposure to either $\mathrm{GuHCl}$ or to $\mathrm{NH}_{4} \mathrm{OH}$. Likewise, treatment of ECMcoated dishes with $\mathrm{HNO}_{2}$ resulted in a $91.6 \%$ inhibition of neurite outgrowth (Table IV).

In order to see if chondroitin sulfates could be involved in neurite outgrowth, ECM-coated dishes were exposed to chondroitinase ABC. Such treatment resulted in only 
a $22 \%$ decrease in neurite outgrowth (Table IV), suggesting that, among the proteoglycans known to be present within the ECM, chondroitin sulfates play little role in neurite outgrowth.

Treatment of ECM-coated dishes with $14 \mathrm{M} \mathrm{NH}_{4} \mathrm{OH}$, $4 \mathrm{M} \mathrm{GuIICl}$, or $2.5 \% \mathrm{HNO}_{2}$ slightly, but insignificantly, reduced the rate of attachment of $\mathrm{PC} 12$ cells relative to control dishes over a 2 -hr period (Fig. 8). Cells were observed to flatten in a manner similar to ECM controls. Thus, although the cells attached to treated plates almost as quickly as to controls, no neurites were initiated. This indicates a possible difference between cell attachment and neurite outgrowth factors.

Neurite outgrowth on ECM prepared in the presence of xyloside or previously exposed to PC12 cells. The above chemical treatments of ECM resulting in greatly decreased neurite outgrowth suggest that, if their effect is as specific as it is on isolated glycosaminoglycans or proteoglycans, then the decreased neurite outgrowth might correlate with the loss or inactivation of glycosaminoglycans in the ECM. However, $\mathrm{GuHCl}$ and $14 \mathrm{M}$ $\mathrm{NH}_{4} \mathrm{OH}$ can denature proteins and $\mathrm{HNO}_{2}$ will react with any primary amino group. Thus, the results can only suggest a role for glycosaminoglycans.

Xyloside acts as a competitive acceptor of the preformed glycosaminoglycan side chain and thus inhibits proteoglycan synthesis. The addition of xyloside to the growth medium of BCE cells used to prepare ECMcoated dishes resulted in essentially complete inhibition of the synthesis and deposition of sulfated glycosaminoglycans into the ECM (Nevo et al., 1982). This xylosideprepared ECM was still capable of initiating neurite outgrowth in a manner similar to untreated ECM (an average of $43 \%$ of the cells had neurites on day 2). Thus, glycosaminoglycans, or at least the carbohydrate portion of a proteoglycan, seem to be unnecessary for neurite outgrowth.

To test whether PC12 cells can consume the factor in ECM responsible for neurite outgrowth directly, PC12 cells were grown to confluence on ECM-coated dishes in the presence of $\beta-\mathrm{NGF}(50 \mathrm{ng} / \mathrm{ml})$. 'The $\mathrm{PCl} 2$ cells then were removed by treatment with $20 \mathrm{~mm} \mathrm{NH}_{4} \mathrm{OH}$, the procedure originally used to prepare the ECM capable of supporting neurite outgrowth. Cells plated on such ECM attached and flattened but did not exhibit neurite outgrowth. This would suggest that the factor in the ECM responsible for neurite outgrowth was either completely consumed or was inactivated by the first PC12 culture.

Modulation of protein synthesis as a function of the substratum upon which PC12 cells were exposed and as a function of whether cells were exposed to NGF. To determine the changes in protein synthesis that occurred in PC12 cells in response to the substratum upon which they were maintained and to NGF, we have examined cultures labeled with [ ${ }^{3: 5}$ S] methionine (days 3 to 5) maintained on collagen- or ECM-coated dishes exposed or not to NGF by two-dimensional gel electrophoresis. The autoradiograms corresponding to cultures maintained on collagen versus ECM and exposed or not to NGF for 5 days are shown in Figure 9. Although no qualitative changes in cellular protein synthesis could be observed between cultures maintained on collagen gels versus those maintained on ECM-coated dishes, quantitative differences were apparent, particularly in the high molecular weight $(>85,000)$ protein region (Figs. $9, A$ and $B$, and $10, A$ and $B$ ). When cultures maintained on collagencoated dishes were exposed to NGF, there was a preferential decrease in the labeling of high molecular weight protein (Fig. 9C). Th [ $\left.{ }^{35} \mathrm{~S}\right]$ methionine-labeled protein distribution tended to resemble that of cells maintained on ECM-coated dishes (Fig. 9B).

The synthesis of a new protein in NGF-treated dishes could be readily detected regardless of whether cultures were maintained on collagen-coated dishes (Fig. $9 C$ ) or ECM-coated dishes (Figs. $9 D$ and $10 D$ ). This protein has a molecular weight similar to that of tubulin $\left(M_{\mathrm{r}}=55,000\right.$ to 56,000$)$ and has a slightly more neutral isoelectric point ( $\mathrm{pH} 5.6$ versus $\mathrm{pH} 5.1$ to 5.2 for tubulin). The same protein also was detected (4-hr labeling) in cultures which were maintained on ECM in the absence of NGF for 2 days and which exhibited neurites (D. K. Fujii, S. L. Massoglia, N. Savion, and D. Gospodarowicz, unpublished results). Cells were cultured on ECM for 5 days in the presence of NGF ( $100 \mathrm{ng}$ of $\beta$-NGF $/ \mathrm{ml}$ ). The cells were extracted under conditions which leave the microtubules and associated cytoskeletal components attached to the substratum (Solomon et al., 1979). The NGF or neurite-induced protein was found to remain with the cytoskeletal components (D. K. Fujii, S. L. Massoglia, N. Savion, and D. Gospodarowicz, unpublished results).

When PC12 cells were labeled in a manner similar to that of Garrels (1979) and Garrels and Schubert (1979) but using only $100 \mu \mathrm{Ci}$ of $\left[{ }^{35} \mathrm{~S}\right]$ methionine, no difference was found in the labeling patterns when compared to cultures labeled as described under "Materials and Methods" either for the same length of time ( $4 \mathrm{hr})$ or for $48 \mathrm{hr}$.

Modulation of protein secretion as a function of the substratum upon which PC12 cells were exposed and as a function of whether cells were exposed to NGF. When the proteins released by PC12 cells into their media were analyzed as a function of the substratum upon which cells were maintained, no obvious qualitative or quantitative differences were apparent between cultures maintained on collagen- versus ECM-coated dishes (Fig. 11, $A$ and $C$ ). In contrast, when NGF was added to the medium, both qualitative and quantitative changes occurred that were the same regardless of whether cultures were maintained on collagen- (Fig. 11B) or ECM-coated dishes (Fig. $11 D$ ). A greatly increased release of protein with approximate molecular weights of 30,000 and 70,000 (Fig. 11, $B$ and $D$ ) was observed, while the release of all other proteins was greatly reduced.

\section{Discussion}

Growing neurites from cultured nerve cells are in a constant process of extension and retraction. Factors which stabilize the extended state would induce neurite formation and elongation. The concept that the strength of neuron adhesion to its substratum is an important regulatory factor for neurite initiation and outgrowth is supported by recent evidence. Studies on the interaction of chick embryonic sensory neurons with tissue culture dishes coated with collagen, polyornithine, polylysine, or 


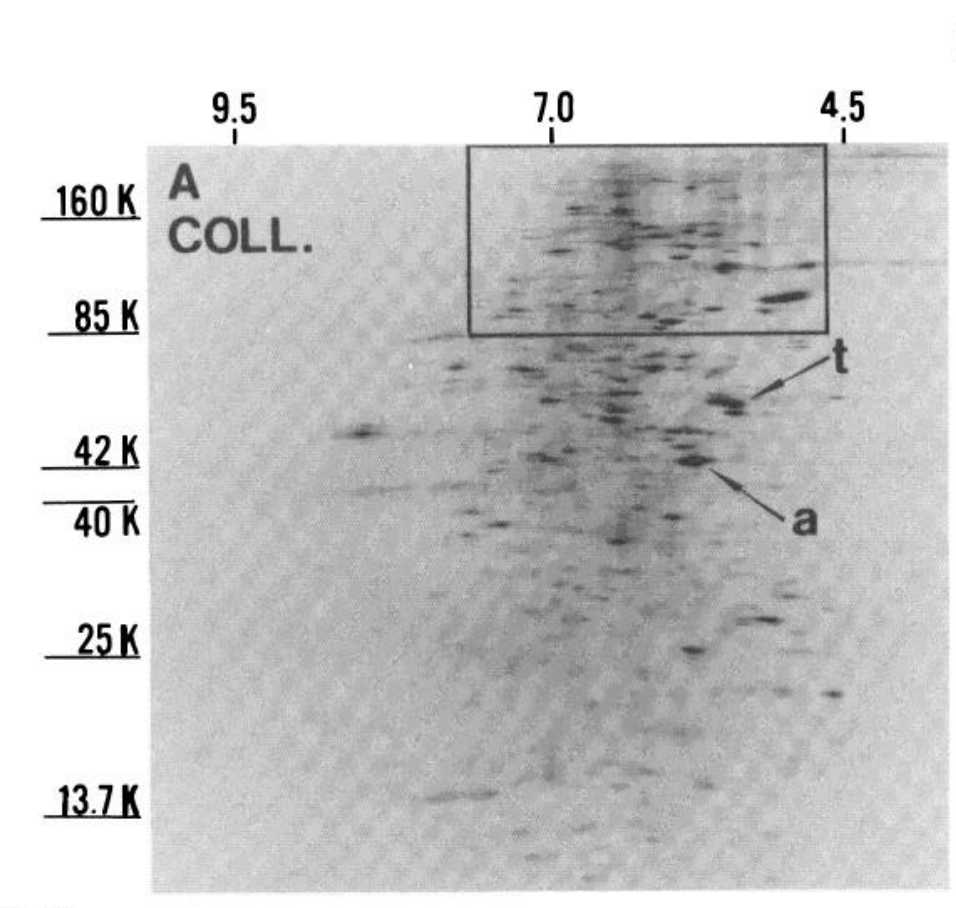

pH

M.W.
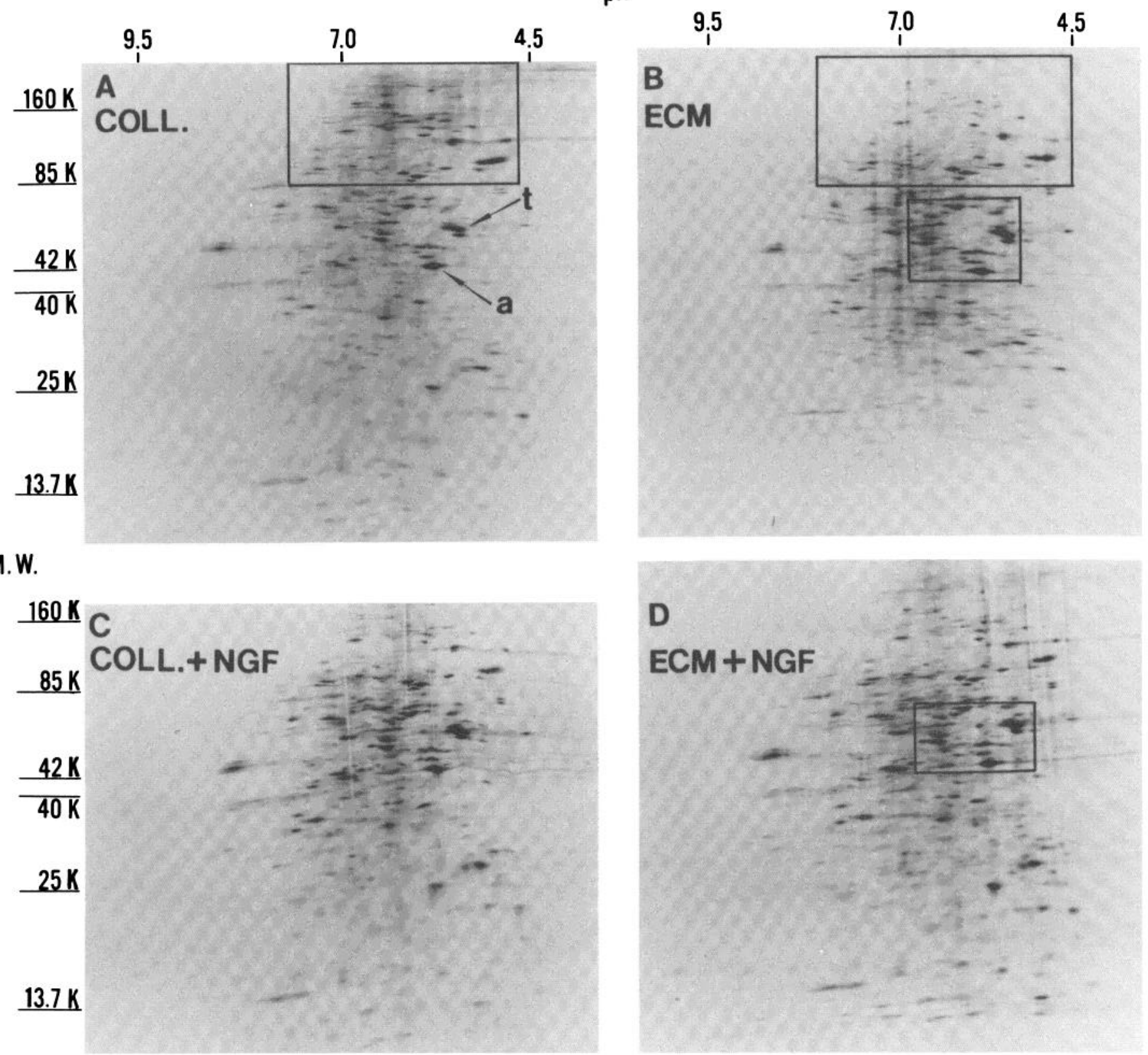

Figure 9. Cellular protein synthesis by PC12 cells on collagen- or ECM-coated dishes in the presence or absence of NGF. PC12 cells $\left(3 \times 10^{5}\right.$ cells/35-mm dish) were dissociated with trypsin and plated onto collagen- or ECM-coated dishes in $2 \mathrm{ml}$ of growth medium in the presence or absence of $7 \mathrm{~S} \mathrm{NGF}(3 \mu \mathrm{g} / \mathrm{ml})$. On day 3 , the cells were washed two times with methionine-free RPMI 1640. One milliliter of methionine-free RPMI 1640 supplemented with $1 \%$ heat-inactivated horse serum, $2 \mathrm{~mm}$ glutamine, and $\left.{ }^{35} \mathrm{~S}\right]$ methionine (60 to $70 \mu \mathrm{Ci}$ ) then was added to the culture. After $48 \mathrm{hr}$, the cells were washed and prepared for isoelectric focusing $\left(2 \times 10^{5} \mathrm{cpm} / \mathrm{sample}\right)$ and SDS electrophoresis as described in the text, and the autoradiograms were exposed for 3 days. The numbers of cells recovered from duplicate dishes were $1.3 \times 10^{5}$ (collagen), $1.3 \times 10^{5}$ (collagen plus NGF), $1.75 \times 10^{5}$ (ECM), and $3.4 \times 10^{5}$ (ECM plus NGF). No neurites were present on day 5 in the cultures not exposed to NGF. Double gels of PC12 cells were plated onto collagen- $(A$ and $C$ ) or ECM-coated ( $B$ and $D)$ dishes and with $(C$ and $D$ ) or without $(A$ and $B)$ NGF. The larger rectangles in $A$ and $B$ are the high molecular weight regions $\left(\mathrm{M}_{\mathrm{r}}>85,000\right)$ and are enlarged in Figure $10, A$ and $B$. The smaller rectangles in $B$ and $D$ show the area where the NGF-induced protein is located and are enlarged in Figure $10, C$ and $D$. In $A$, the arrows indicate tubulin $\left(t ; M_{\mathrm{r}}=55,000 ; \mathrm{pH} 5.1\right.$ to 5.2) and actin $\left(a ; M_{\mathrm{r}}=42,000 ; \mathrm{pH} 5.4\right)$. The four figures are aligned vertically and horizontally by the tubulin and actin spots.

polyglutamate have demonstrated that firm adhesion to the substratum increases the probability of axon initiation, the rate of axonal elongation, and the degree of axonal branching (Letourneau, 1975a, b). Likewise, the long term survival and differentiation of sympathetic neurons required strong adhesion of the neuronal processes to the substratum (Hawrot, 1980). Studies using interference reflection optics support the notion that cell- 

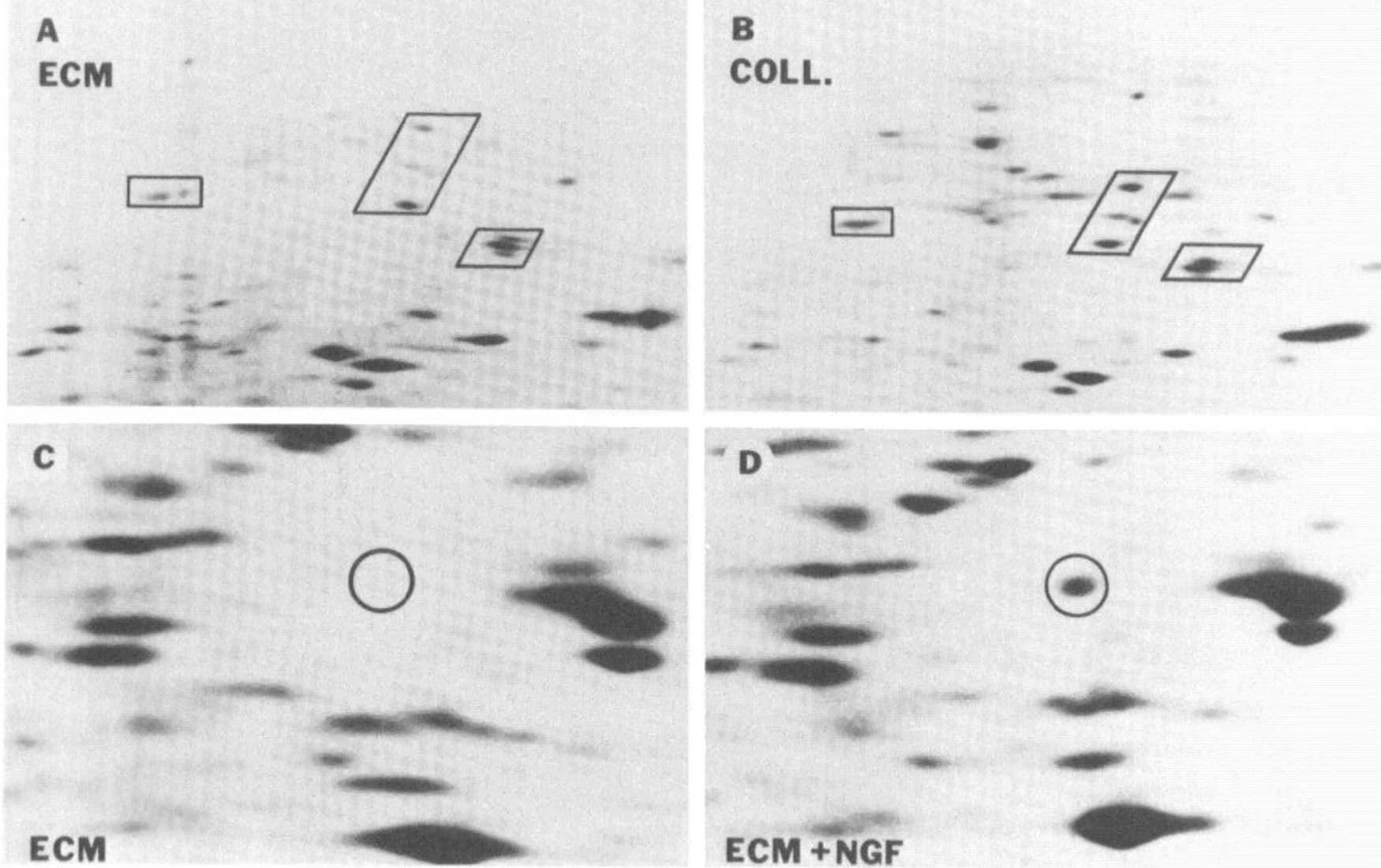

Figure 10. Enlargement of areas of Figure 9. $A$ and $B$, The large enclosed areas in Figure $9, A$ and $B$, are enlarged here to show greater detail. $A$ shows the high molecular weight $(>85,000)$ region of the gel for PC12 cells grown on ECM for 5 days. $B$ is the same for cells grown on collagen-coated dishes. The three pairs of similar rectilinear figures were drawn to act as reference points and were chosen arbitrarily. $C$ and $D$, The smaller enclosed areas in Figure $9, B$ and $D$ are enlarged here to show greater detail. $C$ shows the gel of PC12 cells grown on ECM for 5 days. $D$ shows the same but for cells grown in the presence of $3 \mu \mathrm{g}$ of 7 $\mathrm{S} \mathrm{NGF} / \mathrm{ml}$. The circle indicates the area where the NGF-induced protein is located.

substratum adhesion stabilizes the extension of the growth cone margin and may promote nerve fiber extension through its influence on the organization of the microfilaments within the growth cone (Letourneau, 1979).

Recent studies with the PC12 cell line have shown that NGF increases the rate of cell-substratum adhesion and have suggested that this enhanced adhesion is ultimately responsible for neurite outgrowth (Schubert and Whitlock, 1977; Schubert et al., 1978). Additional experiments have indicated that increased mobilization of $\mathrm{Ca}^{2+}$ may be responsible for restructuring the cell surface, correlative with enhanced cell-substratum adhesion and neurite extension.

Neurite outgrowth from neurons isolated from ciliary, sympathetic, and sensory ganglia and spinal cord has been enhanced by a factor(s) in the conditioned medium from heart cell cultures (Helfand et al., 1976, 1978; Collins, 1978a, b; Collins and Garrett, 1980; Dribin and Barrett, 1980; Adler and Varon, 1981; Coughlin et al., 1981). The factor(s) apparently needs to be attached to the substratum to be active.

Although the above studies support the conclusion that adhesive interactions with the environment are an important source of developmental information in the formation of neuronal processes (Letourneau, 1975a), a valid criticism of previous experiments done on the interaction of nerve cells with their substratum is the artificial nature of the in vitro substrata provided to the cells (plastic, collagen- or gelatin-coated dishes, surfaces of fixed cells, or chemically coated surfaces subsequently coated or not with conditioned medium).

In vivo, neurite outgrowth and growth cone progression occur in close contact with the basal lamina produced by the various tissues that the elongating nerve fiber will encounter during its development (Roberts, 1976). In the present study, therefore, we have analyzed the interaction of PC12 cells with the ECM produced by cultured corneal endothelial cells. This ECM has been shown to have the biochemical composition of a basal lamina, as it is composed of both interstitial and basement membrane collagen types, proteoglycans, and glycoproteins, such as fibronectin and laminin.

PC12 cells grown on tissue culture plastic adhere very poorly to the substratum and grow mostly as floating cell aggregates. By the criteria of biological responsiveness to several biochemical agents and growth rate, our cells behave much like the original PC12 cell line. This stands in contrast with culture conditions developed by Schubert and Whitlock (1977), which favor the growth of PC12 


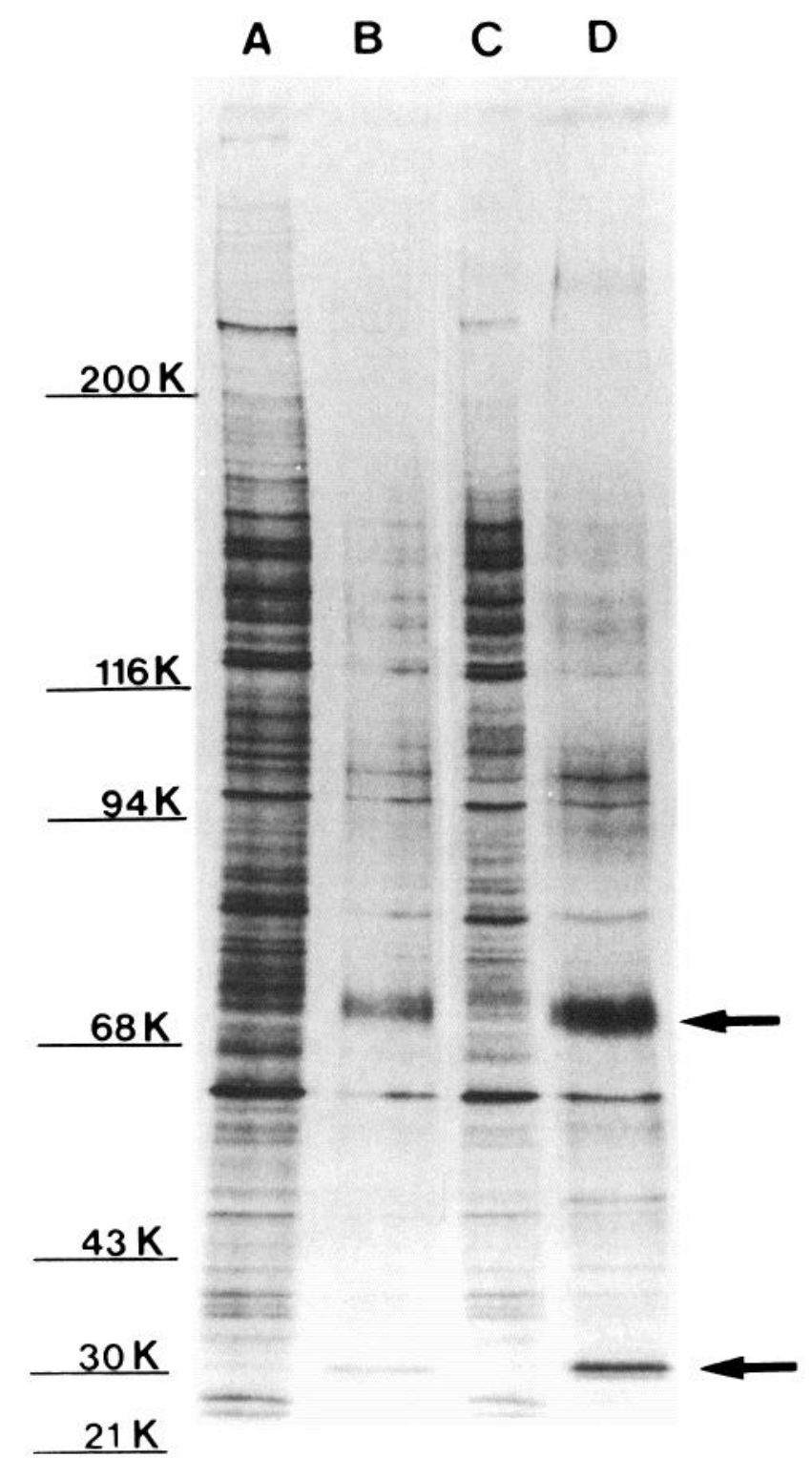

Figure 11. Proteins secreted into the medium by PC12 cells on collagen- or ECM-coated dishes in the presence or absence of NGF. PC12 cells ( $3 \times 10^{5}$ cells $/ 35-\mathrm{mm}$ dish) were plated and NGF was added as in Figure 9. One-half of the medium was changed and NGF was added on days 2 and 4 . On day 6 , the cells were washed as described in the text, and $700 \mu \mathrm{l}$ of the labeling medium, $\left[{ }^{35} \mathrm{~S}\right]$ methionine $(45$ to $50 \mu \mathrm{Ci})$, and $\mathrm{NGF}$, if added previously, were added. After $6 \mathrm{hr}$, the medium was harvested and spun to remove cell debris, and the supernatant was frozen. The numbers of cells recovered from duplicate dishes were $7.8 \times 10^{4}$ (collagen), $8.6 \times 10^{5}$ (collagen plus NGF), $4 \times 10^{5}(\mathrm{ECM})$, and $8.0 \times 10^{5}$ (ECM plus NGF). The samples (3000 cpm each) were run on an SDS slab gel as described in the text and the autoradiograms were exposed for 3 weeks. PC12 cells on collagen-coated dishes without or with 7 S NGF $(3 \mu \mathrm{g} / \mathrm{ml})$ are lanes $A$ and $B$, respectively. Similarly, cells on ECM-coated dishes are lanes $C$ and $D$. The arrows indicate the proteins $\left(M_{\mathrm{r}}=30,000\right.$ and 70,000$)$ whose synthesis was enhanced by NGF.

cells in the attached configuration even when cells are maintained on plastic. Certain biological responses and the growth rate of these PC12 cells differ from those originally reported (Greene and Tischler, 1976).
When the attachment of PC12 cells to ECM-coated dishes versus plastic or collagen-coated dishes was compared, it was observed that cells attach rapidly and tenaciously to ECM-coated dishes. Similar results were obtained with ECM-coated dishes treated with $\mathrm{GuHCl}$, $\mathrm{NH}_{4} \mathrm{OH}$, or $\mathrm{HNO}_{2}$. Following their attachment to the treated or untreated ECM, cells could be observed to spread and flatten, thus reflecting the close association of the cells with this substratum.

It was observed that, even in the absence of NGF, PC12 cells plated on ECM were capable of extending neurites, although for a limited time (5 to 10 days). No such extended response could be observed on either plastic or collagen-coated dishes unless NGF was present. Neurite outgrowth by cells maintained on ECM could be due either to an NGF-like determinant present within the ECM or to adsorbed NGF from the serum. Neither possibility was indicated because NGF antiserum, which blocks the biological response of $\mathrm{PC} 12$ cells to NGF, did not block the neurite outgrowth of cells on the ECM. The presence in the serum of some NGF-like factor to which the cells become responsive when on ECM was unlikely because neurite outgrowth occurred in serumfree medium. Inhibitors of specific metabolic processes were found to decrease or completely eliminate neurite outgrowth. Treatment of ECM with $\mathrm{GuHCl}, \mathrm{NH}_{4} \mathrm{OH}$, or $\mathrm{HNO}_{2}$ greatly decreased neurite outgrowth without a similar decrease in attachment. The xyloside experiments indicate that the glycosaminoglycans are not an important factor in this system. Some isolated components found in ECM were also incapable of supporting neurite outgrowth. It is therefore likely that the increased cellsubstratum adhesion of PC12 cells to ECM versus collagen or plastic surfaces has an important role in neurite outgrowth. This increased cell-substratum adhesion, although necessary for neurite outgrowth, is nevertheless not sufficient. Our results are consistent with the possibility that increased cell-substratum adhesion plays an important role in neurite initiation and outgrowth but also suggest a difference between factors involved in cell attachment and neurite outgrowth. NGF was still required for the long term maintenance and expression of new neurite outgrowth. Thus, NGF's primary action in vivo may not be neurite initiation but long term stabilization of structural components within the growing neurites. Whether NGF accomplishes this stabilization directly, an inference made possible by NGF binding to cytoskeletal elements (see Schechter and Bothwell, 1981; Nasi et al., 1982) or indirectly, by altering cellular metabolism, is not resolved by this study.

The increased rate of neurite elongation and branching observed on ECM-coated dishes could result from increased adhesiveness of the advancing growth cone on such a substratum. In addition, the frequent formation of microspikes from the neurite to the ECM substratum might allow a more efficient adhesion of the elongating neurite to the ECM than that to a plastic or collagen substratum. Such stabilization of adhesion also might support the formation of additional growth cones, leading to branching neurites.

The decline in the percentage of cells bearing neurites after day 2 in the absence of NGF might be explained by the possibility that the active component(s) in ECM is 
consumed or inactivated. Cultures of $\mathrm{PC} 12$ cells plated onto ECM previously covered by PC12 cells did not exhibit neurite outgrowth. This observation would be consistent with the complete cellular consumption of the active component(s) in the ECM. Normally, cells were plated at a low density $(50,000 / 35-\mathrm{mm}$ dish) for the neurite outgrowth assay. Since the cells were still sparse even by day 7 when most, if not all, of the neurites had retracted, it seems unlikely that the cells had consumed all the active component(s) in the ECM directly. A more likely explanation would be that PC12 cells, like many other tumor cells (see Varani et al., 1979), secrete a variety of degradative enzymes (e.g., proteases) and that these enzymes destroy the active component(s). This would be consistent with the results of the protease inactivations of ECM in Table IV. Another possibility is that, since the cells enter a logarithmic growth phase after about 8 days on ECM, the entrance of cells into a phase of the cell cycle which does not permit morphological differentiation results in neurite retraction.

The ECM produced by BCE cells probably has some similarities to the substratum-associated microexudate produced by several non-neuronal cells previously reported to enhance neurite outgrowth from normal neuronal cells (Collins, 1980; Hawrot, 1980) which were exposed to NGF in vivo. Hawrot (1980) has suggested that fibronectin or a glycosaminoglycan might be involved in his microexudate. Our experiments with fibronectin, as well as those of Dribin and Barrett (1980), were negative, and Collins (1980) reported that an antibody to fibronectin did not reduce his microexudate's effectiveness. A recent report by Akers et al. (1982) indicates that fibronectin can support neurite outgrowth by chick neural retinal cells under serum-free or very low serum conditions. This probably indicates that specific systems may or may not be responsive under a given set of conditions. Thus, no generalization should be made.

Since most of the components of ECM can be found in soluble form in the tissue culture media of various cell types capable of producing such a matrix (Vlodavsky and Gospodarowicz, 1981), the possibility exists that the components of the ECM which mediate cell adhesion and neurite outgrowth are similar to those found in the conditioned media of various cell types. A number of investigators have reported that various cells from several species are capable of producing a conditioned medium factor(s) which must be adsorbed to a surface to enhance neurite outgrowth by several types of normal neuronal cells (Helfand et al., 1976, 1978; Collins, 1978a, b; Collins and Garrett, 1980; Dribin and Barrett, 1980; Adler and Varon, 1981; Coughlin et al., 1981; Henderson et al., 1981; Varon et al., 1981). As yet, a positive identification of the neurite-stimulating factor(s) (the presence of NGF has been excluded) or its mechanism of action has not been possible, but enhanced cell-substratum adhesion may be an important factor. Our experiments with conditioned medium did not strongly suggest that a factor(s) was present in the conditioned media from corneal and vascular endothelium which could be physically adsorbed to a surface and thus promote neurite outgrowth from PC12 cells. However, all of the above studies by others were done with normal neuronal cells which probably had axons prior to isolation and were either previously exposed to NGF or did not require NGF for survival and neurite extension. Thus, the PC12 cells might not be a sensitive enough assay or are just not responsive under the assay conditions. PC12 cells on collagen-coated substrata have been shown to express neurites when cultured with a conditioned medium produced by the C- 6 glioma cell line (Edgar et al., 1979). The factor is apparently not NGF, and a need for substratum attachment was not investigated.

Increased substratum adhesion also was reflected by quantitative changes in cellular protein synthesis but not secretion. This was best observed when one compared the pattern of proteins synthesized by $\mathrm{PC} 12$ cells maintained on collagen gel versus ECM. A reduction in the labeling by $\left[{ }^{35} \mathrm{~S}\right]$ methionine of high molecular weight proteins could be observed readily with cultures maintained on ECM. In contrast, when one compared the various proteins secreted by the cells maintained on either substratum, no obvious differences could be observed. In the presence of NGF, qualitative changes in cellular protein synthesis also took place which were the same regardless of the substratum (either collagen or ECM) upon which cells were maintained. Particularly interesting was the observation of the induction of synthesis of a new protein with a molecular weight of 55,000 to 56,000 and an isoelectric point of 5.6. Cultures on ECM exhibiting neurites (e.g., day 2) in the absence of NGF also contain the protein, which is apparently associated with the cellular cytoskeleton. While this cellular protein has the same molecular weight as the substratum attachment molecule described by Schubert (1977), no protein of similar molecular weight was observed in either the secretion studies described below or in cell surface labeling experiments using lactoperoxidase (D. K. Fujii, S. L. Massoglia, N. Savion, and D. Gospodarowicz, unpublished results). Although it has been reported by others (McGuire et al., 1978; Garrels and Schubert, 1979) that, for PC1 2 cells, NGF causes only quantitative modulations of protein synthesis which are the same as those caused by cAMP analogs, our data indicate that qualitative changes can occur as well.

Nilsen-Hamilton et al. (1980) reported that certain growth factors (epidermal and fibroblast growth factors) affected the rate of synthesis of secreted proteins more than of cellular ones. NGF also strongly affected the distribution of proteins released into media by $\mathrm{PC} 12$ cells. This was reflected by the strong induction of release of two proteins with molecular weights of 70,000 and 30,000 and the repression of secretion of proteins with a high molecular weight (above 100,000). The 30,000-dalton protein may be the same protein whose synthesis was increased by NGF in glucosamine-labeled PC12 cells as reported by McGuire et al. (1978). Such modulation of protein secretion by NGF was identical regardless of the substratum upon which cells rested (either collagen or ECM). Such results suggest that NGF has an effect on phenotypic expression that is complementary to that of the substratum. It is also possible that the decrease in overall protein secretion by $\mathrm{PC} 12$ cells in the presence of NGF might limit the secretion of degradative enzymes, resulting in a stabilization of neurites.

In conclusion, the adhesive interaction of nerve cells with the ECM produced by cultured corneal endothelial 
cells may not only provide a new model with which to study the trophic and chemotactic effects of NGF on neurites developing on a natural substratum but also may prove to be useful for the development in culture of neurons from the central nervous system which require intimate contact with glial cells for survival and growth (Sensenbrenner, 1977). Although the role of glial cells may be to provide a trophic factor, it is equally possible that they could provide a suitable microenvironment (such as extracellular material) for mediating neuronal cell adhesion and axon outgrowth (Hatten and Liem, 1981).

\section{References}

Adler, R., and S. Varon (1981) Neuritic guidance by polyornithine-attached materials for ganglionic origin. Dev. Biol. 81: $1-11$.

Akers, R. M., D. F. Mosher, and J. E. Lilien (1982) Promotion of retinal neurite outgrowth by substratum-bound fibronectin. Dev. Biol. 86: 179-188.

Barile, M. F., H. E. Hopps, M. W. Grabowski, D. B. Riggs, and R. A. DelGiudice (1973) The identification and sources of mycoplasmas isolated from contaminated cell cultures. Ann. N. Y. Acad. Sci. 225: 251-264.

Buskirk, D. R., J. -P. Thiery, U. Rutishauser, and G. M. Edelman (1980) Antibodies to a neural cell adhesion molecule disrupt histogenesis in cultured chick retinae. Nature 285: $488-489$.

Castellani, A. A., C. Bladuinia, and A. Brovelli (1970) Regulatory role of UDP-xylose on the biosynthesis of glycosaminoglycans in cornea. In Chemistry and Molecular Biology of the Intercellular Matrix, E. Balazs, ed., Vol. 2, pp. 921-928, Academic Press, New York.

Chen, T. R. (1977) In situ detection of mycoplasma contamination in cell cultures by fluorescent Hoechst 33258 stain. Exp. Cell Res. 104: 255-262.

Cifonelli, J. A. (1968) Reaction of heparitin sulfate with nitrous acid. Carbohydr. Res. 8: 233-242.

Collins, F. (1978a) Axon initiation by ciliary neurons in culture. Dev. Riol. 65: 50-57.

Collins, F. (1978b) Induction of neurite outgrowth by a conditioned medium factor bound to the culture substratum. Proc. Natl. Acad. Sci. U. S. A. 75: 5210-5213.

Collins, F. (1980) Neurite outgrowth induced by the substrate associated material from nonneuronal cells. Dev. Biol. 79: $247-252$.

Collins, F. and J. E. Garrett, Jr. (1980) Elongating nerve fibers are guided by a pathway of material released from embryonic nonneuronal cells. Proc. Natl. Acad. Sci. U. S. A. 77: 66266628.

Connolly, J. L., L. A Greene, R. R. Viscarello, and W. D. Riley (1979) Rapid sequential changes in surface morphology of $\mathrm{PC} 12$ pheochromocytoma cells in response to nerve growth factor. J. Cell Biol. 82: 820-827.

Coughlin, M. D., E. M. Bloom, and I. B. Black (1981) Characterization of a neuronal growth factor from mouse heart-cellconditioned medium. Dev. Biol. 82: 56-68.

de la Torre, J. C. (1980) $\Lambda \mathrm{n}$ improved approach to histofluorescence using the SPG method for tissue monoamines. J. Neurosci. Methods 3: $1-5$.

Dribin, L. B., and J. N. Barrett (1980) Conditioned medium enhances neuritic outgrowth from rat spinal cord explants. Dev. Biol. 74: 184-195.

Edgar, D., Y. -A. Barde, and H. Thoenen (1979) Induction of fibre outgrowth and choline acetyltransferase in $\mathrm{PC} 12$ pheochromocytoma cells by conditioned media from glial cells and organ extracts. Exp. Cell Res. 121: 353-361.
Feramisco, J. R., and S. Blose (1980) Distribution of fluorescently labeled actinin in living and fixed fibroblasts. J. Cell Biol. 86: 608-615.

Foidart, J. M., E. W. Bere, M. Yaar, S. I. Rennard, M. Gullino, G. R. Martin, and S. I. Katz (1980) Distribution and immunoelectron microscopic localization of laminin, a noncollagenous basement membrane glycoprotein. Lab. Invest. 42: 336342 .

Garrels, J. I. (1979) Two-dimensional gel electrophoresis and computer analysis of proteins synthesized by clonal cell lines. J. Biol. Chem. 254: 7961-7977.

Garrels, J. I., and D. Schubert (1979) Modulation of protein synthesis by nerve growth factor. J. Biol. Chem. 254: 79787985.

Gospodarowicz, D., and G. Greenburg (1979) The coating of bovine and rabbit corneas denuded of their endothelium with bovine corneal endothelial cells. Exp. Eye Res. 28: 249-265.

Gospodarowicz, D., and G. Greenburg (1981) The role of growth factors and extracellular matrices in the control of mammalian cell proliferation. In The Biology of Normal Human Growth, M. Ritzen, A. Aperia, K. Hall, A. Larsson, A. Zetterberg, and R. Zetterstrom, eds., pp. 1-21, Raven Press, New York.

Gospodarowicz, D., J. Moran, D. Braun, and C. R. Birdwell (1976) Clonal growth of bovine endothelial cells in tissue culture: Fibroblast growth factor as a survival agent. Proc. Natl. Acad. Sci. U. S. A. 73: 4120-4124.

Gospodarowicz, D., A. L. Mescher, and C. R. Birdwell (1977) Stimulation of corneal endothelial cells in vitro by fibroblast and epidermal growth factors. Exp. Eye Res. 25: 75-89.

Gospodarowicz, D., G. Greenburg, H. Bialecki, and B. Zetter (1978) Factors involved in the modulation of cell proliferation in vivo and in vitro: The role of fibroblast and epidermal growth factors in the proliferative response of mammalian cells. In Vitro 14: 85-118.

Gospodarowicz, D., G. Greenburg, J. -M. Foidart, and N. Savion (1981) The production and localization of laminin in cultured vascular and corneal endothelial cells. J. Cell Physiol. 107: 173-183.

Greene, L. A. (1977) A quantitative bioassay for nerve growth factor (NGF) activity employing a clonal pheochromocytoma cell line. Brain Res. 1.33: 350-353.

Greene, L. A., and E. M. Shooter (1980) The nerve growth factor: Biochemistry, synthesis and mechanism of action. Annu. Rev. Neurosci. 3: 353-402.

Greene, L. A., and A. S. Tischler (1976) Establishment of a noradrenergic clonal line of rat adrenal pheochromocytoma cells which respond to nerve growth factor. Proc. Natl. Acad. Sci. U. S. A. 73: 2424-2428.

Gunning, P. W., G. E. Landreth, M. A. Bothwell, and E. M. Shooter (1981) Differential and synergistic actions of nerve growth factor and cyclic AMP in PC12 cells. J. Cell Biol. 89: $240-245$.

Haffke, S. C. and N. W. Seeds (1975) Neuroblastoma: The $E$. coli of neurobiology? Life Sci. 16: 1649-1658.

Hascall, V. C., and S. W. Sajdera (1969) Proteinpolysaccharide complex from bovine nasal cartilage. The function of glycoprotein in the formation of aggregates. J. Biol. Chem. 244: 2384-2396.

Hatten, M. E. and R. K. H. Licm (1981) Astroglial cells provide a template for the positioning of developing cerebellar neurons in vitro. J. Cell Biol. 90: 622-630.

Hawrot, E. (1980) Cultured sympathetic neurons: Effects of cell-derived and synthetic substrata on survival and development. Dev. Biol. 74: 136-151.

Helfand, S. L., G. A. Smith, and N. K. Wessells (1976) Survival and development in culture of dissociated parasympathetic neurons from ciliary ganglia. Dev. Biol. 50: 541-547.

Helfand, S. L., R. J. Riopelle, and N. K. Wessells (1978) Non- 
equivalence of conditioned medium and nerve growth factor for sympathetic, parasympathetic, and sensory neurons. Exp. Cell Res. 113: 39-45.

Henderson, C. E., M. Huchet, and J. -P. Changeux (1981) Neurite outgrowth from embryonic chicken spinal neurons is promoted by media conditioned by muscle cells. Proc. Natl. Acad. Sci. U. S. A. 78: 2625-2629.

Johnston, R. N., and N. K. Wessells (1980) Regulation of the elongating nerve fiber. Curr. Top. Dev. Biol. 16: 165-206.

Kosher, R. A., and R. L. Searls (1973) Sulfated mucopolysaccharide synthesis during the development of Rana pipiens. Dev. Biol. 32: 50-68.

Laemmli, U. K. (1970) Cleavage of structural proteins during the assembly of the head of bacteriophage T4. Nature 227: $680-685$.

Letourneau, P. C. (1975a) Possible roles for cell-to-substratum adhesion in neuronal morphogenesis. Dev. Biol. 44: 77-91.

Letourneau, P. C. (1975b) Cell-to-substratum adhesion and guidance of axonal elongation. Dev. Biol. 44: 92-101.

Letourneau, P. C. (1979) Cell-substratum adhesion of neurite growth cones, and its role in neurite elongation. Exp. Cell Res. 124: 127-138.

Lindahl, U., and L. Roden (1972) Carbohydrate-peptide linkages in proteoglycans of animal, plant, and bacterial origin. In Glycoproteins, Part A, A. Gottschalk, ed., pp. 491 517, Elsevier, Amsterdam.

Luduena, M. A. (1973) Nerve cell differentiation in vitro. Dev. Biol. 33: 268-284.

MeGarrity, G. J., J. Sarama, and V. Vanaman (1979) Factors influencing microbiological assay of cell-culture mycoplasnilas. In Vitro 15: 73-81.

McGuire, J. C., L. A. Greene, and A. V. Furano (1978) NGF stimulates incorporation of fucose or glucosamine into an external glycoprotein in cultured rat $\mathrm{PC} 12$ pheochromocytoma cells. Cell 15: 357-365.

Millar, T. J., and K. Unsicker (1981) Catecholamine-storing cells in the adrenal medulla of the pre- and postnatal rat. Cell Tissue Res. 217: 155-170.

Nasi, S., D. Cirillo, L. Naldini, P. C. Marchisio, and P. Calissano (1982) Microtubules and mcrofilaments in fixed and permeabilized cells are selectively decorated by nerve growth factor. Proc. Natl. Acad. Sci. U. S. A. 79: 820-824.

Nevo, Z., R. Gonzalez, and D. Gospodarowicz (1982) The identification and possible function of proteoglycans present in the extracellular matrix synthesized by cultured bovine corneal endothelial cells. J. Biol. Chem., in press.

Nilsen-Hamilton, M., J. M. Shapiro, S. L. Massoglia, and R. T. Hamilton (1980) Selective stimulation by mitogens of incorporation of ${ }^{35} \mathrm{~S}$-methionine into a family of proteins released into the medium by 3T3 cells. Cell 20: 19-28.

O'Farrell, P. H. (1975) High resolution two-dimensional electrophoresis of proteins. J. Biol. Chem. 250: 4007-4021.

O'Farrell, P. Z., H. M. Goodman, and P. H. O'Farrell (1977) High resolution two-dimensional electrophoresis of basic as well as acidic proteins. Cell 12: 1133-1141.

Orly, J., and G. Sato (1979) Fibronectin mediates cytokinesis and growth of rat follicular cells in serum-free medium. Cell 17: 295-305.

Roberts, A. (1976) Neuronal growth cones in an amphibian embryo. Brain Res. 118: 526-530.

Rollins, B. J., and L. A. Culp (1979) Preliminary characterization of the proteoglycans in substrate adhesion sites of normal and virus-transformed murine cells. Biochemistry 18: 56215629 .
Ruoslahti, E., M. Vuento, and E. Engvall (1978) Interaction of fibronectin with antibodies and collagen in radioimmunoassay. Biochim. Biophys. Acta 534: 210-218.

Saito, H., T. Yamagata, and S. Suzuki (1968) Enzymatic methods for the determination of small quantities of isomeric chondroitin sulfates. J. Biol. Chem. 243: 1536-1542.

Sajdera, S. W., and V. C. Hascall (1969) Proteinpolysaccharide complex from bovine nasal cartilage. A comparison of low and high shear extraction procedures. J. Biol. Chem. 244: 7787.

Savion, N., and D. Gospodarowicz (1980) Patterns of cellular peptide synthesis by cultured bovine granulosa cells. Endocrinology 107: 1798-1807.

Schechter, A. L., and M. A. Bothwell (1981) Nerve growth factor receptors on $\mathrm{PC} 12$ cells: Evidence for two receptor classes with differing cytoskeletal association. Cell 24: 867874.

Schubert, D. (1977) The substrate attached material synthesized by clonal cell lines of nerve, glia and muscle. Brain Res. 132: $337-346$.

Schubert, D., and C. Whitlock (1977) Alterations of cellular adhesion by nerve growth factor. Proc. Natl. Acad. Sci. U. S. A. $74: 4055-4058$.

Schubert, D., S. Humphreys, F. De Vitry, and F. Jacob (1971) Induced differentiation of a neuroblastoma. Dev. Biol. 25: 514-546.

Schubert, D., M. LaCorbiere, C. Whitlock, and W. Stallcup (1978) Alterations in the surface properties of cells responsive to nerve growth factor. Nature 273: 718-723.

Sensenbrenner, M. (1977) Dissociated brain cells in primary cultures. In Cell, Tissue, and Organ Cultures in Neurobiology, S. Federoff and L. Hertz, eds., pp. 191-213, Academic Press, New York.

Solomon, F. (1981) Guiding growth cones. Cell 24: 279-280.

Solomon, F., M. Magendantz, and A. Salzman (1979) Identification with cellular microtubules of one of the co-assembling microtubule-associated proteins. Cell 18: 431-438.

Timpl, R., H. Rohde, P. G. Robey, S. I. Rennard, J. -M. Foidart, and G. R. Martin (1979) Laminin-a glycoprotein from basement membranes. J. Biol. Chem. 254: 9933-9937.

Tischler, A. S., and L. A. Greene (1978) Morphologic and cytochemical properties of a clonal line of rat adrenal pheochromocytoma cells which respond to nerve growth factor. Lab. Invest. 39: 77-89.

Tseng, S. C. G., N. Savion, D. Gospodarowicz, and R. Stern (1981) Characterization of collagens synthesized by bovine corneal endothelial cell cultures. J. Biol. Chem. 256: 33613365.

Varani, J., W. Orr, and P. A. Ward (1979) Cell-associated proteases affect tumour cell migration in vitro. J. Cell Sci. 36: 241-252.

Varon, S. S., and R. P. Bunge (1978) Trophic mechanisms in the peripheral nervous system. Annu. Rev. Neurosci. 1: 327361

Varon, S. S., S. D. Skaper, and M. Manthrope (1981) Trophic activities for dorsal root and sympathelic ganglionic neurons in media conditioned by Schwann and other peripheral cells. Dev. Brain Res. 1: 73-87.

Vinores, S., and G. Guroff (1980) Nerve growth factor: Mechanism of action. Annu. Rev. Biophys. Bioeng. 9: 223-257.

Vlodavsky, I., and D. Gospodarowicz (1981) Respective involvement of laminin and fibronectin in the adhesion of human carcinoma and sarcoma cells. Nature 289: 304-306. 